
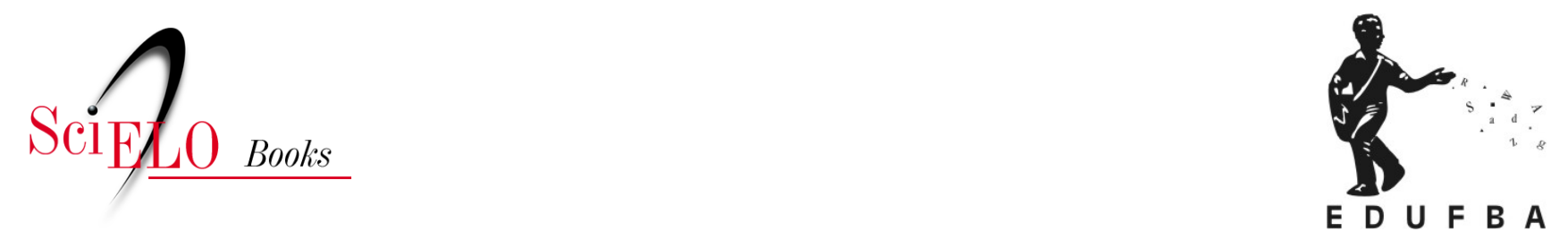

\title{
Contextos comunicacionais e percursos metodológicos
}

\author{
Danila Gentil Rodriguez Cal
}

\section{SciELO Books / SciELO Livros / SciELO Libros}

CAL, D.G.R. Contextos comunicacionais e percursos metodológicos. In: Comunicação e trabalho infantil doméstico: política, poder, resistências [online]. Salvador: EDUFBA, 2016, pp. 105-148. ISBN: 978-85-232-1870-6. https://doi.org/10.7476/9788523218706.0007.

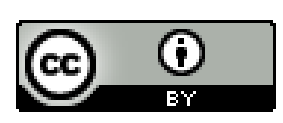

All the contents of this work, except where otherwise noted, is licensed under a Creative Commons Attribution $\underline{4.0 \text { International license. }}$

Todo o conteúdo deste trabalho, exceto quando houver ressalva, é publicado sob a licença Creative Commons Atribição 4.0. 


\section{Contextos comunicacionais e percursos metodológicos}

- No caso, assim, para reparar [criança] em casa, porque até o teu irmão é desde pequeno mesmo. A vida inteira mesmo, desde cedo, porque a tua mãe vai trabalhar e com quem teu irmão vai ficar?

Michelle, participante do Grupo focal "Projeto social”.

O objetivo do presente capítulo é apresentar a importância de considerar, no propósito deste livro, as perspectivas dos media e das afetadas. Num segundo momento, detalhamos as escolhas e o percurso metodológico da pesquisa e tentamos lançar luz acerca dos desafios que foram enfrentados.

Na construção da luta pública contra o TID, as organizações à frente dessa iniciativa atribuíram papéis fundamentais aos media, tais como: meios de expressão do discurso do trabalho infantil enquanto problema social; meios para sensibilização de possíveis parceiros e de autoridades e agentes de transforma- 
ção social. (CENTRO DE DEFESA DA CRIANÇA E DO ADOLESCENTE, 2002; VIVARTA, 2003) Ainda que os esforços e estratégias de comunicação do Petid não fossem centrados exclusivamente nos media, ${ }^{1}$ esses eram considerados atores essenciais no processo de enfrentamento do TID pela possibilidade de promover o debate acerca da temática e também de estimular o questionamento às bases culturais que o alimentam. (CENTRO DE DEFESA DA CRIANÇA E DO ADOLESCENTE, 2002; VIVARTA, 2003)

Essa relação com os media foi considerada exitosa por parte dos atores sociais do Petid, como é possível observar nos documentos avaliativos do Programa. A publicação de matérias e entrevistas nos media locais é apresentada como um dos principais resultados alcançados pela iniciativa nos relatórios técnicos do Petid. (CENTRO DE DEFESA DA CRIANÇA E DO ADOLESCENTE, 2001a, 2001b, 2001c, 2002, 2004; CAVALCANTE, 2005) O relato referente ao período de abril a setembro de 2003, por exemplo, afirma que "Todos os meios de comunicação estão atuando no programa e convencidos de que o trabalho doméstico infantil é prejudicial, o que tem levado a uma maior informação da sociedade sobre o tema”. (CENTRO DE DEFESA DA CRIANÇA E DO ADOLESCENTE, 2003, p. 10) Essa percepção dos próprios atores do Programa corrobora empiricamente nossa afirmação, apresentada no capítulo dois, de que os media locais atuaram como agentes de advocacy em torno do TID e que contribuíram para esse fato a articulação do Petid com um dos principais grupos de Comunicação local e a realização de encontros e oficinas para jornalistas acerca do tema.

Acerca desse assunto, o assessor de imprensa do Petid, de 2003 a 2005, afirmou em uma pesquisa de avaliação do Petid: ${ }^{2}$

[...] Eu acho que o Programa conseguiu colocar o assunto na pauta do dia, chamou as organizações, a imprensa, o poder público; chamou à responsabilidade todo mundo para discutir esse problema, problematizou isso, que é necessário dar soluções. (CAVALCANTE, 2005, p. 76)

1 Outras estratégias previam comunicação dirigida a públicos específicos como empresários, lideranças religiosas e comunitárias, gestores municipais, parceiros das redes de atendimento municipal e estadual à criança e ao adolescente. (CENTRO DE DEFESA DA CRIANÇA E DO ADOLESCENTE, 2002)

2 Trata-se do estudo Acompanhamento e Avaliação Parcial do Programa de Prevenção e Erradicação do Trabalho Infantil Doméstico no Pará: lições aprendidas, desenvolvido, em 2004, pela pesquisadora da Universidade Federal do Pará (UPFA), Lília Cavalcante, por meio de consultoria ao Cedeca-Emaús. 
A importância dos media na opinião dos agentes do Petid fica evidente na medida em que àqueles é atribuída responsabilidade pelo enfrentamento do problema. Partindo da premissa, então, de que os media apoiaram a luta contra o TID, torna-se essencial questionar: como esse assunto foi tematizado na cena pública?

Nossa investigação anterior (CAL, 2007) contribuiu para ensaiarmos possíveis respostas. Percebemos, ao longo daquela pesquisa, que as principais fontes consultadas eram ligadas ao Petid e/ou a seus parceiros e que discursos legitimadores do TID não tiveram espaço no noticiário. Embora os resultados encontrados na análise apresentassem um achado positivo em relação ao modo como os media deram acesso a fontes e enquadraram as organizações sociais, concluímos que o tipo de abordagem não contribuiu para estimular um processo reflexivo entre patroas de meninas trabalhadoras domésticas acerca da temática. Todas as participantes de nossa pesquisa ${ }^{3}$ tendiam a concordar com o que os jornais traziam (que os fatos apresentados eram uma violência, que crianças e adolescentes deveriam ter seus direitos respeitados etc.), porém, fizeram uma diferença radical entre o TID apresentando pelos media, considerado por elas como "exploração do trabalho", e a prática que ocorria nos seus lares, considerada "apenas" trabalho. (CAL, 2007)

As patroas ouvidas nos grupos focais se referiam às situações apresentadas nos jornais com indignação, mas não se sentiam interpeladas porque os pontos de vista que compartilhavam - como o de que há uma distinção entre exploração do trabalho infantil e o TID - não foram considerados na produção jornalística. Era como se o discurso dos media dissesse respeito apenas aos patrões que "exploram" meninas trabalhadoras domésticas, e não àquelas mulheres comuns que empregam meninas para o serviço doméstico, o que trazia consequências importantes do ponto de vista da mobilização social e do estímulo à reflexão crítica acerca do TID porque, se o objetivo era desestimular a contratação de adolescentes para o serviço doméstico, o modo como o discurso público do trabalho infantil como um problema vinha sendo construído até então acabava por reforçar a ideia de que o "problema" estava no fato de alguns patrões explorarem as crianças e não no TID em si.

3 Para a pesquisa de mestrado, foram realizados cinco grupos focais com patroas de meninas trabalhadoras domésticas de distintas classes sociais. 
Daquele estudo, emergiram novos questionamentos focados, sobretudo, nos sujeitos diretamente envolvidos, ou seja, nas trabalhadoras infantis domésticas, as quais tentamos considerar neste livro no sentido de analisar como certo "jogo" entre distintas relações de poder repercute na configuração política do TID e se revela a partir do modo como elas mesmas tecem sentidos sobre essa atividade.

Conforme sugere Allen (2000), o caminho metodológico para pesquisas sobre poder precisa passar pela observação do modo pelo qual dinâmicas de poder participam da constituição de (1) lugares e posicionamentos para os sujeitos, (2) significados culturais, (3) práticas sociais, (4) instituições e (5) estruturas. (ALLEN, 2000) Tomaremos como foco investigativo as três primeiras macrocategorias, já que estamos interessadas em compreender como a articulação entre distintas facetas do poder (power over, powerto e powerwith) traz consequências para configuração política do TID, dos pontos de vista simbólico/discursivo, e a partir dos sentidos mobilizados pelos próprios sujeitos envolvidos.

Como já indicado, escolhemos examinar dois "contextos comunicativos" distintos para responder ao nosso problema de pesquisa: (1) a repercussão do TID nos principais media impressos locais; (2) os discursos de trabalhadoras e ex-trabalhadoras infantis domésticas, apreendidos por meio de grupos focais.

Os media foram selecionados por constituírem a esfera central de visibilidade sobre o TID e também terem atuado como agentes de advocacy. (MAIA; CAL, 2014) Ainda que, à primeira vista, esse fato se apresente como positivo, é necessário observá-lo mais detidamente e indagar como meninas trabalhadoras domésticas foram posicionadas nessa teia discursiva e como as relações de poder em torno do TID são reveladas na análise da cena midiática.

Responder a essas questões traz elementos para examinarmos a construção do TID como um problema político. Porém, os resultados de uma análise do posicionamento dos sujeitos na teia discursiva e da tematização midiática do TID não seriam suficientes para dar respostas satisfatórias ao nosso problema de pesquisa. Seria necessário ainda saber como as pessoas diretamente afetadas pelo TID atribuem sentido a essa prática e como o jogo entre relações de poder, como a dominação, a resistência e a solidariedade, atua na configuração política do TID a partir dos próprios sujeitos concernidos. Há diferenças entre o tratamento dado pelos media ao tema e o modo como esses sujeitos leem as próprias vivências, tal como detectamos com as patroas (CAL, 2007)? O TID como problema político se configura do mesmo modo nessa teia discursiva midiática e nos 
relatos dessas mulheres? O que isso pode revelar, por um lado, sobre a atuação dos media na configuração do TID como questão política e, por outro, sobre a percepção e o entendimento dessas mulheres acerca da questão? E, principalmente, quais desenhos das relações de poder que intervém no TID podem ser percebidos a partir da análise da cobertura midiática sobre esse tema?

Como técnica de coleta de dados, optamos por entrevistas em grupos focais com meninas e mulheres que são ou foram trabalhadoras domésticas na infância ou na adolescência. Essa escolha implica sérios desafios éticos e metodológicos, por exemplo: como ouvir esses sujeitos de modo a não reforçar a opressão? Como discernir o que é resultado de operações de poder nas falas delas? Após a discussão sobre a importância de considerar, nesta pesquisa, tanto as perspectivas dos media quanto das afetadas, detalharemos nosso posicionamento acerca dessas implicações metodológicas.

\section{AS PERSPECTIVAS DOS MEDIA}

Conforme vimos, os media tiveram um papel central na tematização do TID como problema social, de acordo com os agentes do Petid. Apesar de já termos lançado um olhar sistemático para esses materiais nos primeiros cinco anos de ação do Programa (CAL, 2007), não estávamos preocupados naquele momento em observar a constituição de lugares e posicionamentos para meninas e mulheres que foram trabalhadoras domésticas na infância ou na adolescência e o modo como isso diz das relações de poder que atravessam e sustentam essa prática. Além disso, examinar por um período mais longo os materiais dos media, desta vez 10 anos de cobertura, permitir-nos-á analisar como relações de poder atuam na construção de significações culturais em torno do TID e como esses discursos se convertem em práticas, sobretudo políticas, que constituem nosso foco de investigação.

Como afirma Gamson (2011), os agentes midiáticos se encontram engajados na produção e construção de discursos, constituindo espaços onde se instauram complexas disputas simbólicas com as quais sujeitos interpretantes interagem: "Esse sistema cultural encontra indivíduos pensantes e a consciência política emerge do entrecruzamento desses dois níveis”. (GAMSON, 2011, p. 12) Para esse autor, portanto, não se trata de pensar como os indivíduos respondem aos estí- 
mulos midiáticos, mas sim como se processam disputas simbólicas que surgem do entrecruzamento entre as perspectivas dos media e as dos sujeitos.

De modo complementar, França (2006) argumenta que a “publicização” de um texto se dá enredada num certo enquadramento que mobiliza os sujeitos. Esses, por sua vez, "respondem neste enquadramento trazendo outras referências: 'agenciados', inseridos nos nós de uma rede, eles atualizam naquela experiência, experiências anteriores”. (FRANÇA, 2006, p. 84) Portanto, o que se torna objeto de nossa análise não é isoladamente a construção do TID nas matérias dos media, nem a natureza social das trabalhadoras infantis domésticas, mas sim o processo de interação comunicativa, "o cerne da relação, a força que coloca os sujeitos ou interlocutores produzindo sentido, sendo afetados pelo outro e pelo terceiro (o social, o polo da cultura), afetando o outro e o terceiro”. (FRANÇA, 2006, p. 85) Desse objetivo, decorre a importância de considerar as perspectivas dos media e dos sujeitos afetados sob o prisma da interação, como lugar de forças, "como lugar, espaço ou forma que suscita a ação (intervenção) e permite/ acolhe a mudança”. (FRANÇA, 2006, p. 85)

Baseamo-nos também em Rousiley Maia (2008a), para quem os materiais dos media

[...] são potencialmente transformadores das relações do cotidiano.

Esses bens simbólicos, ao dramatizar conflitos vivenciados concretamente pelos indivíduos na sociedade ou trazer elementos de um mundo distante, ou um conjunto de questões e valores estendidos no tempo e no espaço, podem fornecer insumos para a politização das experiências pessoais. (MAIA, R., 2008a, p. 209)

Nessa perspectiva, a tematização midiática de injustiças pode estimular o questionamento de práticas arraigadas, como o TID, e propiciar que esse assunto seja considerado político, sobre o qual a sociedade, de forma mais ampla, precisa discutir. Ao mesmo tempo, sujeitos que vivem ou viveram a experiência do TID podem, em interação com os textos dos media, ressignificá-las e construir novos sentidos acerca desse assunto.

Rousiley Maia (2012) afirma, ainda, que os media são responsáveis por boa parte das informações e dos discursos que alimentam contextos comunicativos. Segundo a autora, as audiências refletem acerca dos materiais dos media e os 
utilizam em processos de discussão. (MAIA, R., 2012) "Os media criam novas oportunidades, novas opções e novas arenas para que os sujeitos produzam sentido de si mesmos, da relação com os outros, o que frequentemente se entrelaça com as instituições e os padrões culturais arraigados”. (MAIA, R., 2008b, p. 209, grifo do autor). Nesse sentido, não se trata apenas de tematizar o TID no espaço de visibilidade dos media, como os agentes do Petid o fazem ao considerarem a publicação de matérias por si um resultado importante, mas de entender o modo como essa tematização midiática reverbera em processos de interlocução, ressignificação e politização.

Entretanto, há perspectivas pessimistas em relação ao potencial político e social dos media. Por exemplo, as primeiras formulações de Habermas em relação aos grandes meios de comunicação, organizadas no seu repercutido livro Mudança Estrutural da Esfera Pública (1962), apontavam para um declínio da esfera pública. Bastante influenciado pela concepção adorniana de "indústria cultural”, o autor conclui que teria ocorrido uma perda da autonomia e da capacidade crítica do público, o que teria levado ao declínio da vida pública na sociedade de massas (MAIA, R., 2008b, 2012; HABERMAS, 2003; GOMES, 2008). Segundo Rousiley Maia (2012):

\footnotetext{
Com o desenvolvimento da indústria cultural, a mídia eletrônica e impressa, organizadas como corporações, começam a responder à lógica do capital e do mercado. Voltando-se para o entretenimento, os meios de comunicação constroem uma linguagem desprovida de seu aspecto crítico, a qual começa a permear as relações sociais e dominar a linguagem cotidiana. Neste cenário, a imprensa comercial - esse é o argumento - já não tem a intenção de proporcionar oportunidades para os cidadãos participarem no debate público. (MAIA, R., 2012, p. 60-61, tradução nossa)
}

Já em Direito e Democracia (2003), o autor apresenta aspectos positivos dos media que incidem na esfera pública, como, por exemplo, a generalização dos debates, ao envolver sujeitos dispersos espacialmente. Habermas (2003), então, considera os media uma tipologia de esfera pública, "a esfera pública abstrata", acompanhada por outros dois tipos: a esfera pública episódica e a de presença organizada. 
Habermas esclarece que estabeleceu essa diferenciação a partir da densidade da comunicação, do alcance e da complexidade organizacional dessas esferas parciais. (HABERMAS, 2003) Nesse sentido, a esfera episódica diz respeito a interações simples, relacionadas à vida cotidiana, as quais escapam ao controle de governos e instituições. As trocas argumentativas, nessa instância, são efêmeras e com alcance limitado. (MAIA, R., 2012) Habermas (2003) cita como exemplos as discussões que ocorrem em bares, cafés, encontros nas ruas. A esfera pública de presença organizada é exemplificada por encontros de pais, reuniões de partidos, conferências, assembleias e fóruns de organizações da sociedade civil. Segundo Rousiley Maia (2012), nesse ambiente comunicativo, as trocas argumentativas ocorrem de modo mais estruturado, a partir de uma pauta e de regras e procedimentos para debate. Por fim, o terceiro tipo de esfera pública apresentado por Habermas é a abstrata, produzida pelos media, que envolvem "leitores, ouvintes e espectadores singulares e espalhados globalmente" (HABERMAS, 2003, p.107) e são responsáveis pelo principal âmbito de visibilidade na contemporaneidade. Por utilizarem uma linguagem comum, acessível, de modo geral, aos cidadãos de diferentes locais, distintas condições educacionais e sociais, os media podem contribuir para a generalização de debates na esfera pública.

Não é nosso objetivo desenvolver com mais detalhes o conceito de esfera pública e as perspectivas de seus críticos, porém consideramos necessário esclarecer em linhas gerais o conceito, que contribui para pensarmos no papel dos media em processos de inovação social e cultural. Desse modo, entendemos esfera pública como ambiente comunicativo que emerge a partir da discussão de temas específicos em diferentes arenas. (HABERMAS, 2003) De acordo com Habermas, a esfera pública pode ser considerada uma caixa de ressonância enraizada na sociedade e, por isso, permeável e sensível aos problemas e demandas que advêm do mundo da vida. Assim, a esfera pública é constituída através da linguagem e da relação intersubjetiva por meio do discurso que, em termos habermasianos, refere-se ao processo argumentativo a partir do qual reivindicações de validade podem ser testadas. (HABERMAS, 1984, v.1; CAL, 2007) Segundo Habermas (2003), “a esfera pública constitui principalmente uma estrutura comunicacional do agir orientado pelo entendimento, a qual tem a ver com o espaço social gerado no agir comunicativo”. (HABERMAS, 2003, p. 92) Portanto, a esfera pública não pode ser confundida com instituições ou organizações. (HABERMAS, 2003) 
Nesse sentido, a tipologia dos media como esfera pública abstrata pode gerar o entendimento equivocado de que os media seriam "a” esfera pública. Por essa razão, autores como Gomes (1999) e Rousiley Maia (2008b) argumentam que os media teriam a capacidade de pré-estruturar a esfera pública, ao dar visibilidade para as diversas razões envolvidas em uma mesma discussão. Dessa forma, "Quando ideias novas e relevantes são produzidas na periferia da esfera pública, elas precisam de alguma forma de atingir o ambiente dos media para se tornarem disponíveis ao público em larga escala”. (MAIA, R., 2012, p. 72, tradução nossa)

Em relação ao TID, especificamente, a penetração social dos media e a esfera de visibilidade gerada por eles têm potencial não somente para alcançar as casas de família (locus desse tipo de atividade), como também para amplificar a definição do TID como um problema público. Isso porque a esfera de visibilidade midiática "fornece um vasto e profícuo campo para explorar os conflitos e as tensões existentes entre os indivíduos e grupos, [...] para redefinir as fronteiras entre o público e o privado, para proteger ou desafiar culturas e práticas, identidades e valores”. (MAIA, R., 2008b, p. 118)

Se, por um lado, não podemos ignorar as possibilidades dos media em contribuírem com a vida cívica e os valores democráticos, por outro, não podemos, também, superestimá-las. É preciso reconhecer que os media apresentam complexas relações com o sistema político, o mercado e a sociedade (HABERMAS, 2009; MAIA, R., 2012) e que, portanto, não são meros veículos: “Os media não são ‘canais' ou 'provedores neutros' de informação, mas instituições híbridas, ao mesmo tempo políticas, econômicas e cultural-profissionais, que estabelecem relações tensas, conflituosas, com outros atores sociais”. (MAIA, R., 2008b, p. 95)

Ainda assim, é essencial reconhecer que a contribuição política dos media não deve ser deduzida do fato de serem empresas ligadas a elites e grupos poderosos. Os media possuem códigos próprios e rotinas profissionais que não são subjugados ou controlados completamente pelos imperativos do poder ou do dinheiro:

[...] a crescente complexidade da mídia e o aumento do capital acarretam uma centralização dos meios de comunicação. Na mesma proporção, os meios de comunicação ficam expostos a uma crescente pressão seletiva, tanto do lado da oferta, quanto da procura. Esses processos de seleção tornam-se fonte de uma nova espécie de poder, 
ou poder da mídia, o qual não é controlado suficientemente pelos

critérios profissionais. (HABERMAS, 2003, p. 109-110)

Todavia, essa pressão seletiva do ponto de vista empresarial, por exemplo, não impede que os media atuem como agentes políticos ou produzam insumos para a discussão política, já que são também plurais, variados e habitados por outros atores sociais. Há, ainda, pressões advindas da própria sociedade acerca da qualidade e do papel social dos media que influenciam nas produções midiáticas. (PORTO, 2012)

Mendonça (2006) e Rousiley Maia (2008b, 2012) argumentam que os media devem ser pensados de modo ambivalente, já que podem tanto favorecer a democracia quanto prejudicá-la. Sobre esse ponto, Mendonça ressalta: "Ainda que, por meio dele [sistema midiático], cristalizem-se significados e instituições, ele também possibilita a contestação desses e a criação de outras ordens possíveis”. (MENDONÇA, 2006, p. 18) Por essa razão, esses autores trabalham com uma abordagem dos media a partir da ideia de sistema. (WAISBORD, 2010; HABERMAS, 2009; MAIA, R., 2006, 2008b, 2012) Segundo Maia (2012), os media podem ser entendidos como um subsistema social que engloba um conjunto de instituições e de especialistas, que possui regras e modos operatórios próprios e que goza de relativa autonomia em relação a outros sistemas sociais, como o econômico e o político. Diz-se de uma relativa autonomia porque há constrangimentos sociais, técnicos, econômicos e profissionais aos quais os media estão sujeitos. (MARQUES, 2008; MAIA, R., 2011; 2012) Segundo Rousiley Maia (2012), as ações dos media noticiosos (que envolvem decisões acerca de temáticas, enquadramentos e destaques na cobertura) "devem ser consideradas como o resultado da interação dos fatos, a internalização de determinados pressupostos normativos, restrições práticas, e práticas institucionalizadas”. (MAIA, R., 2012, p. 85, tradução nossa)

Rousiley Maia (2012) ressalva que a ideia de sistema deve ser pensada como uma diretriz que dá margem ao entendimento da complexidade dos media e propõe a compreensão dos media não como "meios", mas como "ambientes" nos quais se processam disputas simbólicas. (MAIA, R., 2012; GOMES, W., 2004) De acordo com Rousiley Maia (2006), as formas pelas quais os media operam não permitem uma definição essencializada como "boa" ou "ruim": 
Para desenvolver um entendimento qualificado dos fenômenos comunicativos - e não simples apologia ou mera condenação - é preciso examinar o cruzamento de influências diversas dentro dos processos sociais e políticos. É preciso estar atento para a complexidade desses terrenos, que são multifacetados e devem ser investigados em detalhes, com lupas e tabelas. (MAIA, R., 2006, p. 35)

No caso do TID, os media locais participaram como parceiros do Petid no enfrentamento a essa prática, de tal modo que, em outro momento, concluímos que os media atuaram como agentes de advocacy. (CAL; MAIA, R., 2012; MAIA R.,; CAL, 2012, 2014) Ainda assim, acreditamos que é preciso ter em consideração a complexidade do terreno midiático e lançar um olhar mais atento ao modo pelo qual os media, ainda que reforçassem os enquadramentos propostos pelas organizações sociais acerca do TID, atuaram na construção de sentidos e discursos sobre os lugares atribuídos a meninas trabalhadoras domésticas e a repercussão disso na politização desse assunto.

É possível afirmar que o Petid e seus parceiros realizaram o que Waisbord (2009) chama de "jornalismo de defesa civil" (ou civic advocacy journalism), ao procurar influenciar o noticiário em prol da cobertura do TID. As organizações da sociedade civil, dependendo do tipo de trabalho que desenvolvem, podem ser ouvidas e consideradas pelos media,ainda que não detenham o poder político do Estado ou o poder econômico das grandes empresas. Segundo Waisbord (2010), os media não são apêndices de governos nem do mercado, "em vez disso, os meios de comunicação devem ser entendidos como arenas nas quais interesses concorrentes procuram obter acesso e influência”. (WAISBORD, 2010, p. 136, tradução nossa) Desse modo, o "jornalismo de defesa social” contribui para trazer à cena midiática assuntos e vozes da sociedade civil. As premissas para realização desse tipo de ação são baseadas na ideia de que os media possuem um papel fundamental para realização de transformações sociais e políticas e na construção de problemas públicos. (WAISBORD, 2009) Do modo contrário, “a invisibilidade e deturpação na mídia podem minar os esforços gerais para promover conscientização e políticas públicas”. (WAISBORD, 2009, p. 9, tradução nossa)

Portanto, analisar as perspectivas dos media é parte essencial de pesquisas que envolvam ações e programas sociais que busquem transformações sociais ou políticas. Conforme vimos, há uma aceitação social e cultural dessa prática 
que é realizada, sobretudo, nos ambientes íntimos e privados de lares de família. Assim, os media são importantes, em princípio, nessa configuração política do trabalho infantil, tanto por constituírem o principal palco de visibilidade na contemporaneidade, quanto pelas visadas que lançam acerca das temáticas sociais. Como afirma Gomes, os media constituem-se em um "sistema expressivo formado pelo conjunto da emissão dos meios de comunicação que constitui a esfera de visibilidade pública, tornando disponível ao público, ou ao sistema dos seus apreciadores, uma espécie de quadro do mundo”. (GOMES, W., 2008, p. 143)

Wilson Gomes (2008) caracteriza a cena pública como um ambiente em que convivem conteúdos de distintos valores cognitivos:

A esfera de visibilidade pública é como um mar de sargaços, com fragmentos de discursos de todos os tamanhos, às vezes com peças inteiras, que não compõem nenhum quadro ordenado, mas que o acaso fez conviver e, eventualmente, atritar aos caprichos das correntes marinhas. (GOMES, W., 2008, p. 145)

Ao fazer uso da metáfora do "mar de sargaços", o autor defende a ideia de uma cena pública composta por diferentes discursos que podem se relacionar de acordo com a articulação proposta por atores sociais e políticos ou por agentes da mídia. De modo complementar, Rousiley Maia (2008a) argumenta que "a visibilidade midiática contribui para o estabelecimento de um novo quadro dinâmico de interpretações”. (MAIA, R., 2008a, p. 189) É esse material que fomenta boa parte da discussão sobre questões políticas na esfera pública. Os media correspondem ao principal palco dessa esfera de visibilidade, além disso, permitem a passagem da estrutura espacial das interações simples para a generalização da esfera pública. (HABERMAS, 2003)

Os fragmentos de discursos, as notícias, podem ser caracterizados, de acordo com Gomes (2008), como fundo e tema. Por "fundo", entende-se um conjunto disponível de materiais informativos que "passem 'sob os olhos' do receptor ou destinatário e que perduram por algum tempo na memória sem maiores consequências”. (GOMES, W., 2008, p. 143) Compõem, portanto, um repertório potencial, mas ainda não articulado de tematizações públicas. Desse modo, o "tema" se caracteriza como um conjunto de fragmentos ou materiais expressivos que foram colocados em pauta. Segundo Gomes (2008), eles são ativos intelectual- 
mente e "municiam os discursos e as interações mais argumentativas e organizam a agenda social”. (GOMES, W., 2008, p. 143) Diante do exposto, tematizar um assunto significa trazê-lo à pauta.

Importante ressaltar que organizar é distinto de determinar, o que não significa uma equação exata em relação aos modos como os sujeitos se apropriam dos discursos dos media. Para Gamson, "as pessoas leem as mensagens da mídia de forma complicada complexa e às vezes imprevisível, e se servem intensamente de outros recursos para produzir sentido acerca do universo da política”. (GAMSON, 2011, p. 27, grifo nosso)

Wilson Gomes (2008) e Rousiley Maia (2008b, 2012) concordam que os cidadãos utilizam seus próprios repertórios de experiência para interagir e interpretar os produtos midiáticos. "O sistema expressivo que constitui a cena pública é sempre um sistema interpretado, isto é, estruturado, organizado, agenciado pelos seus interpretes”. (GOMES, W., 2008, p. 146) Rousiley Maia (2008b) afirma também que "os membros do público incorporam os sentidos derivados dos produtos da mídia em seus estoques de conhecimento comum”. (MAIA, R., 2008b, p. 99) E é esse repertório que eles irão utilizar nas interações simples, nas conversações ordinárias, inclusive sobre questões políticas:

[...] a interpretação do produto midiático dá-se sempre a partir de um conhecimento interpretativo anterior, à luz do qual o receptor estabelece o que é relevante, inscreve elementos assim processados nas rotinas práticas da vida cotidiana e utiliza tal material simbólico de maneiras diversas dentro de comunidades particulares e/ou contextos culturais e políticos específicos. (MAIA, R., 2008a, p. 173-174)

Além dos recursos midiáticos, os sujeitos também fazem uso de experiências vividas e da sabedoria popular para construir sentidos acerca de questões políticas. Gamson (2011) realizou uma ampla pesquisa com objetivo de entender como cidadãos comuns, sobretudo, trabalhadores, produzem sentido acerca de assuntos políticos e como os discursos dos media participam dessa construção. $\mathrm{O}$ autor e sua equipe analisaram as conversações em grupos de trabalhadores a respeito de quatro temáticas: problemas enfrentados pelas indústrias americanas; ações afirmativas; energia nuclear e conflito árabe-israelense. A conclusão preliminar - o autor ressalta que a investigação lança mais questionamentos do 
que fornece respostas - é a de que os sujeitos utilizam, de modo complexo e variado, de acordo com a temática, os discursos dos media, a sabedoria popular e o conhecimento experiencial e que os enquadramentos construídos acerca desses assuntos podem ou não conduzir à ação política.

Mesmo em assuntos mais próximos ao cotidiano dos trabalhadores, como o referente aos problemas atravessados pela indústria americana - que geram demissões, fechamento de usinas etc. -, Gamson (2011) afirma que permanece um hiato entre os discursos da mídia e o que as pessoas apresentam como conhecimento advindo da experiência. "Esse hiato pode ser preenchido, mas poucos grupos possuem os recursos para preenchê-los sozinhos e com sucesso, e isso não tem grande probabilidade de acontecer de maneira espontânea”. (Gamson, 2011, p. 229)

Nossa pesquisa se aproxima dessa investigação empreendida por Gamson na medida em que busca analisar como sujeitos fazem sentido acerca de uma questão tematizada nos media de modo consequente para uma atuação política, assim como ocorre em outras investigações que vêm sendo desenvolvidas no âmbito do Grupo de Pesquisa em Mídia e Esfera Pública da Universidade Federal de Minas Gerais (EME/UFMG) (ver especialmente MARQUES, 2007; CAL, 2007; MAIA, R., 2012). No entanto, nossa pesquisa possui contornos e questionamentos distintos, pelo menos por quatro motivos: (a) os sujeitos considerados são aqueles efetivamente afetados pela temática em tela, e não trabalhadores em geral; (b) nosso foco é no modo como relações de poder atuam na configuração política do TID; (c) o fato de haver um Programa que reúne organizações sociais que empreenderam ações de advocacy contra essa prática parece-nos ser um elemento com potencial para diminuir esse hiato entre os discursos dos media e os sentidos sobre a vida cotidiana; (d) a atuação dos media de modo favorável aos enquadramentos do Petid e seus parceiros nos permite investigar as repercussões disso entre os próprios sujeitos afetados.

Ao final do livro em que relata o processo dessa pesquisa, Gamson (2011) dá conselhos a ativistas de movimentos sociais e sugere algumas estratégias. Uma das apresentadas pelo autor para envolver os sujeitos em determinadas causas é promover uma articulação emocional por meio de testemunhos e situações que possam retratar experiências de injustiça. "O discurso público facilita o conhecimento por meio da experiência vicária quando personaliza amplas injustiças utilizando casos exemplares para dar forma a elas”. (GAMSON, 2011, p. 230) 
No entanto, desconfiamos que, quando pensamos em relações de poder e nos lugares atribuídos a determinados sujeitos, essas situações por vezes testemunhadas e tornadas amplamente visíveis pelos media atuam num sentido inverso à mobilização e atuação política dos envolvidos porque os posicionam em condições de dominação, de vitimização e de subalternidade. Por esse motivo, o exame dessa possibilidade e dos questionamentos levantados neste livro precisa considerar necessariamente as perspectivas dos afetados.

\section{AS PERSPECTIVAS DAS "AFETADAS”}

No livro A Ralé Brasileira: quem é e como vive, Souza (2009) indaga diversas vezes sobre o porquê de os indivíduos dessa classe social não reagirem politicamente a formas de humilhação cotidianas: "Por que a sua 'resistência' jamais atinge o estágio político?”. (SOUZA, 2009, p. 410) Como possíveis respostas, Souza (2009) enumera pelo menos três: (a) a autojustificação sobre as condições em que vivem (o que dizem de si é sempre uma justificação, algo para continuar vivendo); (b) a instrumentalização das relações familiares, ou seja, os membros são considerados na medida em que servem à família; (c) o foco no tempo presente para garantir necessidades imediatas, o que dificulta planejamentos a médio e longo prazo. A tese do autor acerca da constituição social e afetiva da ralé, como uma segunda natureza, um poder invisível, esteia essas afirmações. De modo complementar, Souza (2009) afirma que quando os sujeitos da ralé visualizam o futuro, é sempre de modo idealizado como fruto de uma "solução mágica", como ganhar na loteria:

Para os esmagados por uma ordem incompreensível cujo sofrimento não pode deixar de ser vivido não só como natural, mas acima de tudo como 'merecido', pelo efeito da 'culpa individualizada' da ideologia meritocrática percebida como verdade absoluta, resta o devaneio das ‘saídas mágicas' ou o ressentimento individualizado contra 'pessoas'. (SOUZA, 2009, p. 417)

Para esse autor, portanto, o conceito de poder refere-se preponderantemente a processos de dominação, que obscurecem relações de exploração, mesmo para os sujeitos danosamente afetados. E na medida em que os pressupostos da 
dominação são internalizados, "in-corporados" a esses sujeitos, perceber suas atitudes e questionamentos pelo viés da ação política se torna impossível. A premissa do autor é que a "verdade" não é acessível a esses sujeitos e nem no modo como se expressam. "Principalmente o [discurso] dos humilhados e ofendidos, que, por razões óbvias, não podem aceitar subjetivamente a percepção negativa, cheia de suspeita [...] e até abertamente hostil e humilhante que o mundo social faz deles". (SOUZA, 2009, p. 438) Tanto que, para realização da pesquisa, Souza e colaboradores realizaram entrevistas de modo sistemático e frequente com os mesmos sujeitos durante dois anos. Souza (2009) destaca que a informação do entrevistado é essencial, porém afirma que o pesquisador deve "reconstruir a verdade" das informações obtidas para que situações e interesses "inconscientes" e "pré-reflexivos" sejam apreendidos e contextualizados.

Os incômodos e as preocupações de Souza (2009) trazem desafios ànossa pesquisa sobre como ouvir e considerar as falas de meninas e mulheres diretamente envolvidas com o TID nas condições de crias ou empregadas. Entretanto, conforme explicamos no capítulo três, consideramos limitante a visada sobre a atuação política dos indivíduos da ralé. É como se não houvesse saídas, brechas, subversões e rupturas nesse contexto "naturalizado" de opressão, ou como se esses sujeitos fossem completamente destituídos de autonomia e de capacidade expressiva.

Um olhar distinto do de Souza (2009) é lançado por Brites (2003), que, como apresentamos no capítulo três, defende a construção de perspectivas analíticas propícias para observarmos os subalternos não como retrógrados ou alienados, mas sim entender suas práticas políticas de modo contextualizado "para garantir um espaço a partir do qual estes 'outros', não inteiramente cúmplices do ideário moderno, possam participar da própria definição dos processos de participação política”. (BRITES, 2003, p. 78) Importante reafirmar que, tal como Brites, entendemos política de modo alargado, e não apenas vinculado às instituições políticas formais.

Desse modo, considerar as perspectivas dos afetados, desvelando o modo como participam da própria definição de processos políticos é crucial para entendermos, nesta pesquisa, os sentidos atribuídos ao TID e como o jogo entre relações de poder como dominação, resistência e solidariedade atua na configuração política do TID a partir dos próprios envolvidos. Apesar dos desafios éticos, metodológicos e analíticos que essa escolha implica, como explicitare- 
mos adiante, consideramos essencial examinar como esses sujeitos, tão pouco consultados em pesquisas científicas acerca de trabalho infantil, tomam a palavra e se tornam seres de discurso. Klocker (2012) realizou uma ampla pesquisa bibliográfica, que correspondeu ao exame de 1.225 artigos científicos especificamente sobre trabalho infantil, e concluiu que raramente crianças e adolescentes são ouvidos ou considerados: "Crianças e jovens continuam a ser drasticamente sub-representados nos registros da literatura sobre sua vida de trabalho". (KLOCKER, 2012, p. 897, tradução nossa)

Outro argumento que sustenta nossa escolha é o fato de os sujeitos em condições subalternas ou de vulnerabilidade serem considerados majoritariamente como "seres de necessidades", ao invés de "seres de discurso", capazes de tomar a palavra. (RANCIÈRE, 2004; CAL, 2013; MARQUES, 2013) Assim, de modo contrário à visão desses sujeitos como meras vítimas, buscamos considerar as possibilidades de que possam agir politicamente, questionar e refletir sobre aspectos concernentes às suas vidas e a de outros indivíduos e colocar em suspeição certa ordem estabelecida que determinaria os lugares, os papéis de cada um.

Cabe aqui uma explicação sobre a quem nos referimos como afetados. Rousiley Maia (2012) ressalva que a identificação pessoal com uma determinada situação ou causa pode não ser suficiente para definir que sujeitos são afetados por ela. No entanto, seguindo as proposições da autora, é bastante razoável afirmar que meninas e mulheres ex-trabalhadoras infantis domésticas são afetadas por esse tipo de trabalho infantil e concernidas por essa questão. Da mesma forma, poderíamos argumentar que as patroas, as famílias empregadoras, de modo geral, e os agentes de advocacy também o são. No entanto, quando utilizamos o termo "afetada" nesta pesquisa, estamos nos referindo aos sujeitos cuja relação com o TID é extremamente forte, ao ponto de marcar suas experiências e histórias de vida. Estamos nos referindo a quem desempenhou tal atividade por algum tempo durante a infância ou adolescência ou que ainda a desempenha.

Importante ressaltar que nosso trabalho se beneficia de aportes teóricos e metodológicos desenvolvidos por pesquisas acerca de conversações políticas (ELIASOPH, 1998; GAMSON, 2011; MAIA, R., 2012; MARQUES, 2007; WALSH, 2004) e, também, de como se processam trocas argumentativas em âmbitos informais de discussão e de suas relações com o sistema deliberativo mais amplo (MANSBRIDGE, 1999, 2009; MARQUES, 2007; MENDONÇA, 2009), porém, a partir de outro ângulo analítico. Aquelas pesquisas foram cruciais para enten- 
dermos como se articulam direitos e autonomia nas margens do sistema deliberativo (MARQUES, 2007) e como o cruzamento entre diferentes âmbitos interacionais é fundamental na construção discursiva de lutas por reconhecimento esteadas em processos deliberativos. (MENDONÇA, 2009)

A partir desse contexto, nossa investigação objetiva analisar a interação entre os discursos dos media e os das afetadas pelo TID como lugar de forças para compreender como certo jogo entre diferentes facetas do poder atua na configuração dessa questão como um problema político. Portanto, ao invés de nos questionarmos, como o faz Souza (2009), sobre o porquê de esses sujeitos não atuarem politicamente, indagamos: como relações de poder (power over, power to e power with) atuam na configuração política do TID a partir dos próprios afetados, num contexto social em que grupos de advocacy constroem uma luta pública contra esse tipo de trabalho infantil, inclusive, como apoio dos media?

\section{PERCURSO METODOLÓGICO}

Como apresentamos no capítulo três, poder é um dos conceitos mais difíceis de operacionalizar em pesquisas empíricas. (PERISSINOTO, 2008; NOBRE et al., 2008) A diversidade de angulações teóricas pelas quais se aborda o conceito é significativa, do ponto de vista metodológico. Condensamos essa discussão em três visadas sobre "poder", inspirados pela abordagem integrada de Allen (1998, 2000), que propõe a distinção analítica de facetas: power over, power to e power with. Só assim, de acordo com Allen, é possível entender de forma complexa como, em relação a uma mesma situação, por exemplo, as mulheres podem ser tanto subordinadas quanto dominadoras.

Desse modo, a proposta de Allen é pertinente para análise do TID, não somente porque se trata, sobretudo, de uma relação entre mulheres (mãe da menina, patroa e menina doméstica), mas porque permite observar que as visadas sobre poder compõem a face de uma mesma moeda. Essa escolha guiou-se também pela sistemática observação de nossos materiais empíricos que, a nosso ver, demandavam uma concepção mais abrangente acerca do poder, considerando que a maior parte da literatura sobre TID o considera apenas uma forma de dominação. Partimos, então, da premissa de que as práticas de resistência e contestação dessas meninas e mulheres não podem ser desconsideradas. Portanto, 
compreender "a interação entre cada uma dessas formas de exercício do poder é crucial, pois só tal abordagem integrativa será complexa o suficiente para fazer sentido das múltiplas e sobrepostas relações de poder dentro das quais nós mulheres nos encontramos”. (ALLEN, 2000, p. 124, tradução nossa)

Como caminho metodológico para analisar a relação entre essas faces do poder, Allen (2000) sugere a adoção de duas perspectivas: a de primeiro plano (foreground) e a de fundo (background). Dessa forma, passa-se da análise de situações específicas de poder à consideração de contextos mais amplos que as sustentam ou dão sentindo a elas. A lógica é a de que exemplos pontuais de exercício de poder (tanto como power over, power to ou power with) conectam-se a elementos de fundo, como significados partilhados e posições/lugares atribuídos a sujeitos, como, no nosso caso, os modos pelos quais o TID e as meninas trabalhadoras domésticas são simbolicamente situados na teia de poder em torno dessa prática. Todavia, a autora alerta que essa distinção é apenas analítica: "é uma distinção entre diferentes ângulos a considerar quando se estuda as relações de poder na sociedade. Assim, cada perspectiva é uma forma necessária para iluminar a outra”. (ALLEN, 2000, p. 125, tradução nossa)

Portanto, observar em primeiro plano significa, para Allen (2000), descrever relações de poder entre indivíduos ou grupos distintos. Refere-se ao exame de como as três facetas do poder mencionadas anteriormente ganham corpo em situações distintas. No caso do TID, por exemplo, podemos observar como as ex-trabalhadoras infantis domésticas situam casos de dominação por parte de alguma patroa, ou então o modo como resistiram ou questionaram essa prática. Ou, ainda, o modo pelo qual construíram solidariedade em conjunto para lutar contra melhores condições de trabalho ou algo assim.

Por outro lado, o segundo plano analítico permite a compreensão dos sentidos que alimentam essas relações de poder. Para Allen, "Nós precisamos enxergar o poder pelo que eu estou chamando de perspectiva de fundo para entender como relações entre indivíduos distintos passam a ser, por assim dizer, 'power-ed". (ALLEN, 2000, p. 125, tradução nossa) Desse modo, lançar um olhar contextualizado permite compreender o que constitui as relações de poder enquanto tais. Como já dito, Allen indica cinco diferentes aspectos a partir dos quais a background perspective pode ser examinada: (1) lugares e posicionamentos para os sujeitos, (2) significados culturais, (3) práticas sociais, (4) instituições e, por fim, (5) estruturas. (ALLEN, 2000) 
O primeiro aspecto tem foco em esclarecer o modo pelo qual são construídos “os lugares dos sujeitos” e o modo pelo qual indivíduos e grupos são posicionados “numa rede de relações de poder”. (ALLEN, 2000, p. 125, tradução nossa) Assim, permite a compreensão de como as relações de poder moldam os lugares que os sujeitos ocupam no mundo e também como esses lugares podem ser marcados por resistências, rupturas e apresentar múltiplas faces. Segundo a autora, essa complexidade é fundamental porque considera:

\footnotetext{
[...] a natureza múltipla e por vezes contraditória de subject-position é crucial para teorização feminista das formas complexas nas quais mulheres específicas podem ser posicionadas diferentemente dentro do contexto de uma mesma norma, prática ou instituição. (ALLEN, 2000, p. 126, tradução nossa)
}

Sobre os "significados culturais", Allen (2000) destaca que é necessário investigar em pesquisas acerca do poder o modo pelo qual sentidos são construídos, reforçados e codificados culturalmente. Sentidos esses que ajudariam a discutir, por exemplo, os significados de "filha de criação", "trabalho escravo", “TID” num determinado contexto sociocultural e o modo como são construídos simbolicamente contrapontos às perspectivas culturais dominantes acerca dessas conceituações.

Considerar o terceiro aspecto é atentar para a forma como as significações culturais repercutem em "práticas sociais" que podem reforçar relações de dominação ou abrir espaço para questionamentos e/ou ações sociais mais amplas. Significa compreender como determinados entendimentos sobre "filha de criação” se transformam em práticas acerca do papel dessa menina na família substituta, por exemplo, e para construir saídas quando necessário. (ALLEN, 2000)

O quarto aspecto que envolve o segundo plano analítico é o das "instituições”. "As instituições podem reforçar e sustentar relações de poder, endossando entendimentos específicos [...] ou incentivando ou proibindo práticas particulares”. (ALLEN, 2000, p. 128, tradução nossa) Como exemplos, Allen (2000) apresenta empresas e as tensões das colocações da mulher no mundo corporativo, no sistema judiciário e na definição da guarda de crianças e na construção de organizações sociais que oferecem suporte a mulheres vítimas de violência. A perspectiva da autora nesse ponto permanece restrita ao entendimento de instituições. 
Não há referência a perspectivas mais alargadas que consideram, por exemplo, a família como uma instituição. No caso do TID, considerar as instituições seria pensar, por exemplo, o papel do Cedeca-Emaús e de outras organizações de advocacy acerca do modo como questionam ou reforçam relações de poder que envolvem meninas trabalhadoras domésticas.

Por fim, o último aspecto que pode contribuir para elucidar perspectivas de fundo acerca do poder é o das “estruturas”, que podem ser divididas, segundo Allen (2000), em superficiais (surface structures) e de fundo (deep structures). Na primeira, observam-se as relações de poder como estruturas que determinam e influenciam, sobremaneira, situações e contextos sociais (a autora cita como exemplos, "gênero" e "divisão de classes"). A segunda preocupa-se em investigar "as formas pelas quais relações de poder realmente estruturaram nossa situação social” (ALLEN, 2000, p. 129), ou seja, a segunda observa como as relações de poder são estruturantes da primeira.

Apesar de propor esse esquema metodológico geral e de citar exemplos pontuais acerca do feminismo, Allen (2000) não esclarece modos de aplicá-lo à análise de casos concretos nem a produções midiáticas. Portanto, tomamos como inspiração a angulação analítica sugerida pela autora a partir de um plano mais imediato e outro mais profundo e, a partir da interação com nossos objetos empíricos, acreditamos serem mais pertinentes ao nosso objeto de pesquisa, nesse momento, principalmente os três primeiros aspectos levantados por ela: (1) Subject-position; (2) significações culturais e (3) práticas sociais.

Investigar as "posições dos sujeitos” possibilitará a compreensão de como as relações de poder moldam os lugares que as meninas e mulheres afetadas pelo TID ocupam no nosso contexto sociocultural, tanto os que lhes são atribuídos como os que elas se atribuem. Da mesma forma, permitirá, ainda, observar o questionamento dessas posições, quando houver tensões e fraturas num certo quadro dado de possibilidades de meninas e mulheres diretamente envolvidas com o TID.

De modo complementar, examinar as "significações culturais" nos possibilita considerar como as relações de poder ressoam na construção de sentidos compartilhados em torno do TID, e mesmo em torno da condição da menina doméstica, cuja situação é bastante complexa, como discutimos no primeiro capítulo. Observar esse aspecto da perspectiva de fundo permite ainda entender 
como o discurso contrário a esse tipo de trabalho infantil foi construído e sustentado por organizações sociais e pelos media.

Finalmente, analisar as “práticas sociais”é essencial para compreendermos a forma pela qual os sentidos acerca do TID se configuram em práticas sociais e políticas que nos interessam sobremaneira. Acreditamos que podem ser tanto práticas que alimentam e aceitam o TID quanto práticas políticas de resistência, subversão, demonstração da injustiça e organização de luta política propriamente. Para tanto, recorremos, ainda, a Guimarães e França (2006), que entendem discursos como práticas de produção e renovação de estruturas de sentido.

Especificamente acerca das relações de poder, consideramos profícua também a aproximação com os princípios da Análise Crítica do Discurso, segundo os quais, relações de poder são negociadas e encarnadas por meio do discurso, e esses tanto refletem quanto reproduzem práticas sociais. (FAIRCLOGH, 2001, 2013; PALTRIDGE, 2013; WODAK, 2001, 2012) Como afirma Wodak (2001), a linguagem está entrelaçada ao poder social e pode tanto expressá-lo quanto desafiá-lo.

Nesse sentido, Fairclough, Mulderring e Wodak (2011), afirmam que discurso é uma prática social:

[...] discurso é socialmente constitutivo, bem como conformado socialmente: constitui situações, objetos do conhecimento, e as identidades sociais das relações entre pessoas e grupos de pessoas. É constitutivo tanto no sentido de que ele ajuda a sustentar e reproduzir o status quo social, quanto no de que contribui para transformá-lo.

(FAIRCLOUGH; MULDERRING; WODAK, 2011, p. 358, tradução nossa)

Para Fairclough (2001), essa forma de olhar o discurso e as relações de poder "oscila entra o foco na estrutura e o foco na ação". (FAIRCLOUGH, 2001, p. 124, tradução nossa) Fairclough, Mulderring e Wodak (2011) chamam atenção ainda ao fato de que não se pode considerar de modo fixo ou unilateral os aspectos discursivos das relações de poder. Apesar de não desenvolverem a tensão entre o poder que ganha forma por meio do discurso e o poder que age sobre o discurso, eles avaliam que é preciso considerar na análise, a dinâmica entre o power in discourse e o power over discourse. (FAIRCLOUGH, MULDERRING; WODAK, 2011) Poderíamos "complexificar" ainda mais essa tensão, recorrendo ainda a um terceiro tipo de relação entre poder e discurso, que é a ideia do "poder de to- 
mar a palavra” (CAL, 2013; MARQUES, 2013; RANCIÈRE, 1996, 2004), referente à capacidade de falar e de ser ouvido com consideração pelos demais, ou seja, "saber se os sujeitos da interlocução são ou não são, se falam ou se produzem ruído”. (RANCIÈRE, 1996, p. 61)

Sobre esse ponto, é também relevante a perspectiva defendida por Spivak (2010), segundo a qual os grupos subalternos, como as viúvas indianas cuja situação ela analisa, não podem, de fato, falar porque o que dizem não se torna objeto de consideração dos demais. Isso porque o que falam é resultante de operações de poder como dominação, ou ainda, porque a fala delasé frequentemente mediada pela voz de outra pessoa, "que se coloca em posição de reivindicar algo em nome de um(a) outro(a)". (ALMEIDA, 2010, p. 14) Assim, ao longo de nossa investigação, buscamos manter no horizonte de preocupações essas três tensões acerca da relação entre poder e discurso.

Nesse contexto, nosso problema de pesquisa consiste em analisar como relações de poder (power over, power to e power with) atuam na configuração política do TID tanto a partir do ponto de vista das próprias envolvidas, no caso meninas e mulheres ex-trabalhadoras infantis domésticas, quanto no âmbito de visibilidade ampliada dos meios de comunicação, numa conjuntura social em que grupos de advocacy constroem uma luta pública contra esse tipo de trabalho infantil e contam com apoio dos media.

Desse questionamento mais geral, desenvolvemos outras indagações que nos orientaram na busca por respostas e explicações para os fenômenos estudados.

Em primeiro plano:

a) Como meninas e mulheres afetadas constroem sentido acerca dos lugares que lhes são atribuídos? Como elas se posicionam no contexto do TID?

Em segundo plano:

a) Como a abordagem dada pelos media ao TID e os modos pelos quais meninas e mulheres trabalhadoras leem as próprias vivências são marcados por relações de poder? Quais as diferenças entre essas perspectivas?

b) A atitude de endossar ou questionar formas de dominação relacionadas ao TID depende da natureza do assunto em questão (como educação, responsabilidades acerca do TID, a definição de TID, distinções entre tra- 
balho em casa e na casa da patroa e perspectivas de futuro)? Se isso for verdadeiro, como essas distinções reverberam em termos da politização no TID nos media e nos grupos focais?

A seguir, apresentaremos mais detalhadamente o modo pelo qual construímos as ferramentas mais específicas para buscar respostas ao nosso problema de pesquisa e para examinar os eixos analíticos propostos. A transposição entre a abordagem metodológica mais ampla de Allen (2000) e as formas concretas para examinar o material investigado segue como uma proposição nossa, inspirada por outras investigações que acompanhamos ao longo das discussões no Grupo EME/UFMG. ${ }^{4}$

\section{Seleção e escolha do corpus}

Analisaremos dois tipos de material empírico: matérias jornalísticas sobre TID, publicadas nos dois jornais diários paraenses de maior importância e discursos sobre esse tipo de trabalho infantil, reunidos por meio de grupos focais realizados com meninas e mulheres afetadas pelo TID. A investigação desses dois contextos comunicativos é fundamental para chegarmos a respostas adequadas ao nosso problema de pesquisa. Os objetivos desta seção são: detalhar os materiais que compõe o corpus da pesquisa; apresentar alguns elementos gerais relacionados às matérias jornalísticas; explicar a escolha pelo grupo focal como técnica para coleta de dados e explicitar como essa metodologia foi utilizada.

SOBRE AS MATÉRIAS JORNALÍSTICAS

Selecionamos as notícias sobre TID publicadas nos jornais O Liberal e Diário do Pará $^{5}$ no período compreendido entre janeiro de 2000, quando se iniciaram as

4 Somos credores, sobretudo, do aprendizado que obtivemos ao acompanhar as pesquisas desenvolvidas por Marques (2007), Mendonça (2009), Miola (2012) e Maia (2012). Da pesquisa da Profa Ângela Marques, participamos inclusive de um dos grupos de discussão mediados pela ela, realizado na comunidade do Alto Vera Cruz, em Belo Horizonte. Esse aprendizado lançou bases fundamentais que nos permitiram organizar os grupos focais de nossa dissertação de mestrado e na tese de doutorado.

5 Ambos os jornais possuem uma abrangência regional, embora tenham distribuição nacional. O Liberal é mais antigo. Remonta o ano de 1940, porém está sob o comando da família Maiorana, que o administra hoje, desde 1966. Passou por um grande processo de modernização e havia se tornado liderança 
primeiras ações de enfrentamento a esse tipo de trabalho infantil no estado, e dezembro de 2009, quando as ações do Petid estavam em franca diminuição, o que acarretou o encerramento definitivo do Programa em $2010 .{ }^{6}$

A forma pela qual essas matérias foram coletadas variou bastante em razão da não existência de arquivos eletrônicos desses jornais antes de 2007. Os textos de janeiro de 2000 a dezembro de 2004 já estavam em nossa posse porque haviam sido utilizados em nossa investigação de mestrado. (CAL, 2007) A coleta de matérias de 2007 a 2009 foi feita de modo digital, a partir de mecanismos de busca no site dos jornais. As palavras-chave para tanto iam desde expressões bem precisas como "TID”, "trabalho infantil”, "Petid”, "Cedeca-Emaús” a outras mais genéricas que nos demandaram um tempo maior de leitura e seleção como "casa”, “doméstica”, “doméstico". A lacuna dos anos de 2005 e 2006 foi preenchida a partir de leitura e seleção no arquivo físico de clippings sobre infância e adolescência da Agência Unama de Comunicação pela Infância e Adolescência, projeto de extensão da Universidade da Amazônia (Unama), que fazia e arquivava essas coletas desde agosto de $2004 .^{7}$ Após digitalização e leitura das matérias encontradas, selecionamos 193 notícias e reportagens que abordavam o TID. Foram descartadas notícias que apenas o citavam como uma forma de trabalho infantil ou que não problematizavam aspectos envolvidos nessa temática e, ao final, permaneceram 136 matérias a serem analisadas.

absoluta no jornalismo diário paraense, razão pela qual exercia forte influencia sobre a sociedade e as elites estaduais. (VELOSO, 2008) O jornal compõe, junto com emissoras de rádio, emissora de TV (filiada à Rede Globo), um jornal popular, um portal de notícias na Internet e empresa de TV a Cabo, as Organizações Rômulo Maiorana. O Diário do Pará foi criado em 1982 pela família do ex-governador do Pará e atual senador Jader Barbalho, do Partido do Movimento Democrático Brasileiro (PMDB). Faz parte também de um conglomerado midiático que reúne portal de notícias na Internet, emissoras de rádio e uma de TV (filiada à Rede Bandeirantes). Nos anos 2000, o Diário do Pará conseguiu alcançar a liderança de $O$ Liberal, segundo pesquisa do Instituto Brasileiro de Opinião Pública e Estatística (IBOPE) (VELOSO, 2008). O cenário atual é de uma forte disputa empresarial e jornalística entre os dois veículos.

6 Necessário ressaltar que a falta de financiamento externo ao Petid foi determinante para que não houvesse continuidade. Durante a pesquisa de campo, quando conversamos com dirigentes e técnicos do Petid, eles atribuíram a falta de apoio financeiro à imagem positiva que o governo Lula passava da realidade brasileira, o que teria resultado, segundo eles, na saída de investimentos estrangeiros em projetos sociais no país e sua migração para países consideramos mais pobres e necessitados. Situação que merece ser mais bem investigada, mas que não é objeto de preocupação desta pesquisa.

7 Para essas buscas contamos com apoio e recursos do Grupo EME (UFMG), coordenado pela Prof. Rousiley Maia, a quem somos muito gratos. 
O material selecionado foi catalogado e sistematizado através do preenchimento de uma ficha de análise (ver Apêndice A) que resultou na construção de um banco de dados. Os itens avaliados diziam respeito à data de publicação, ao jornal, à editoria, ao gênero jornalístico, à caracterização das fontes ouvidas, especialmente em relação a trabalhadoras ou ex-trabalhadoras infantis domésticas, e ao posicionamento atribuído a esses sujeitos (como vítimas, resistentes, sujeitos políticos ou outro) e temáticas, como discutiremos mais adiante.

Em relação à distribuição por jornal, houve mais publicações sobre TID em O Liberal (64,7\%) do que no Diário do Pará (35,3\%). Consideramos que o principal fator que estimulou essa diferença significativa foi a parceria firmada entre Petid e $O$ Liberal, de tal forma que os eventos relativos ao TID eram cobertos pelo jornal, além de ter havido a publicação de matérias especiais, sobretudo na página de Responsabilidade Social, que circulava no caderno de política todas as quintas-feiras. Em relação à divisão por editorias, a cobertura acerca do TID se concentrou principalmente no caderno atualidades $(54,4 \%)$, seguido pelo de polícia (19,1\%) e pelo de política (13,2\%).

Tabela 1 - Distribuição de matérias por gênero jornalístico

\begin{tabular}{l|lll} 
Gênero jornalístico & Qtd & $\%$ \\
\hline Notícia & 69 & 50,7 \\
\hline Reportagem & 63 & 46,3 \\
\hline Editorial & 2 & 1,5 \\
\hdashline Entrevista & 2 & 1,5 \\
\hline Total & & 136 & 100,0 \\
\hline
\end{tabular}

Fonte: Dados da Pesquisa.

Houve pouca diferença entre o percentual de notícias e reportagens (Tabela 1), provavelmente em razão de termos excluído do nosso corpus matérias que tratavam apenas pontualmente do TID. Mantivemos somente as notícias que abordavam esse tipo de trabalho infantil ou um de seus aspectos de modo relativamente significativo, ou seja, quando o tema em si ou parte dele eram minimamente colocados e discutidos no texto. Excluímos as matérias que apenas citam esse tipo de trabalho infantil. 
No período estudado, encontramos ainda dois editoriais de $O$ Liberal acerca do assunto e duas entrevistas de página inteira que tratavam da temática: uma com a advogada Celina Hamoy, coordenadora do Cedeca-Emáus e outra com Roberta Sandrelli, patroa então acusada de assassinar uma menina de 11 anos que trabalhava como babá.

Gráfico 1 - Variação da cobertura sobre o TID ao longo de 10 anos, por quantidade de matérias

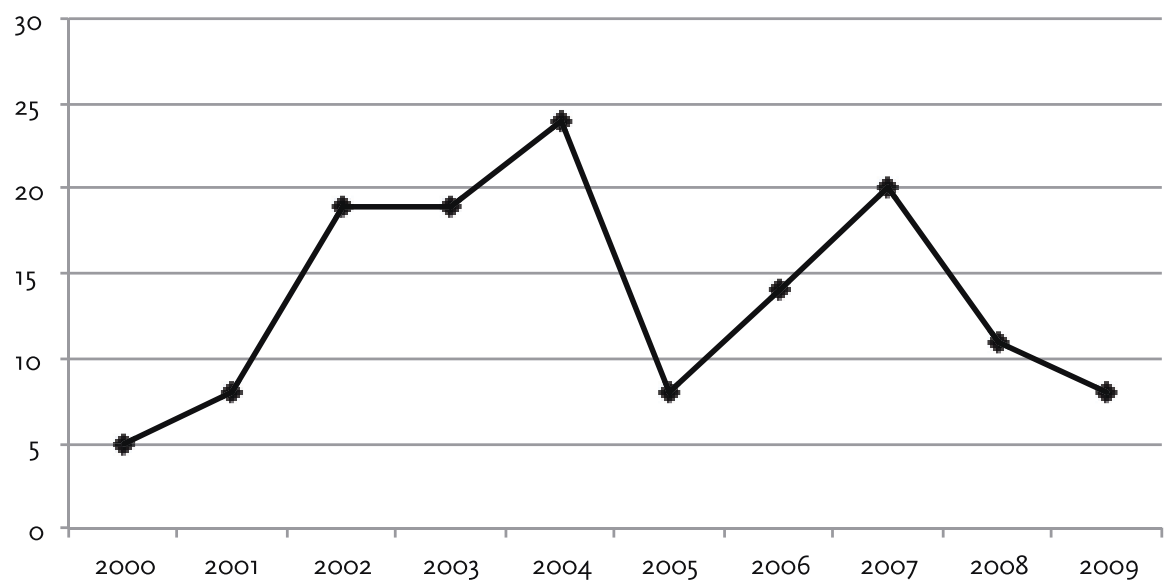

Fonte: Dados da Pesquisa.

A trajetória de crescimento da quantidade de matérias jornalísticas acerca do TID no Pará acompanha o desenvolvimento do Petid e o início da tematização pública desse tipo de trabalho infantil, principalmente por meio da divulgação dos resultados de pesquisas locais e nacionais sobre o assunto. A forte subida em 2002, que foi mantida em 2003, representa os anos de atuação mais consolidada do Programa e o início do financiamento da OIT ao projeto paraense. Nesse período, foram realizadas ainda, pela Andi - Comunicação e Direitos juntamente com o Cedeca-Emaús, oficinas com jornalistas acerca do TID. Em 2004, a subida se acentua quando é lançada a segunda fase da campanha de publicidade do Petid. Em novembro de 2005, ocorreu a morte da menina Marielma de Jesus Sampaio, de 11 anos, assassinada pelos patrões que a levaram de Vigia, cidade do interior do Pará, com a finalidade de se tornar babá da filha deles em Belém. 
O caso e os respectivos desdobramentos legais ganham bastante repercussão entre os anos de 2006 e 2007.

Relevante destacar que, para composição de nosso corpus, consideramos apenas as matérias sobre o caso que problematizaram algum aspecto do trabalho infantil, e não apenas noticiavam os fatos relativos ao crime ou ao julgamento dos acusados. De 2008 a 2009, percebemos uma queda na quantidade de matérias sobre o assunto, porém, nesse período, houve uma quantidade significativa de reportagens que discutiam diferentes nuances do TID. No próximo capítulo, apresentaremos em detalhes como ocorreu essa cobertura e a relação dos discursos dos media com as falas das pessoas afetadas por essa problemática. Antes, porém, apresentaremos aspectos metodológicos relacionados aos grupos focais.

\section{GRUPOS FOCAIS}

A decisão pela realização de grupos focais como método de investigação e coleta de dados ocorreu por os considerarmos espaços propícios para discussão acerca do TID. Esse método é considerado bastante adequado para examinar experiências, opiniões e preocupações dos sujeitos. (KITZINGER; BARBOUR, 2001) Ainda mais porque possibilita a interconexão entre diferentes vivências e opiniões, o que pode oportunizar a construção de novos vieses e pontos de vista acerca de problemas comuns. Segundo Kitzinger e Barbour, "Participantes dos grupos focais têm a oportunidade de juntar as experiências fragmentadas dos membros do grupo e poder passar a ver os eventos em suas próprias vidas sob uma nova luz no curso de tal discussão”. (KITZINGER; BARBOUR, 2001, p. 19, tradução nossa)

Devemos ressaltar que a finalidade dos grupos focais não poderia ser a de reproduzir ambientes de conversação cotidianas dessas meninas e mulheres. Não se trata de defender o método ou a validade da realização desses grupos por meio de justificativas para tentar aproximá-lo de condições realmente compartilhadas no dia a dia pelas entrevistadas. Partimos da premissa de que os grupos focais são ambientes previamente organizados, mas que podem se tornar ricos espaços de interação entre aquelas meninas e mulheres e que são capazes de estimular construções de sentido em conjunto. Além disso, nosso objetivo é investigar as relações de poder a partir dos discursos sobre o TID, o que também poderia, sem 
dúvida, ser percebido por meio de entrevistas individuais e do aprofundamento em histórias de vida. ${ }^{8}$

Todavia, nossa questão de pesquisa é mais ampla e abrange as possibilidades de configuração política do TID a partir das próprias envolvidas. Além disso, como vimos no capítulo três, a politização de determinados temas envolve necessariamente discussão. Portanto, o processo de interação nos grupos nos pareceu mais rico e relevante do que apenas entrevistas individuais. Como afirma Marques (2007):
[...] as pessoas, ao conversarem e trocarem pontos de vista umas com as outras, podem melhorar formas de pensar e de interpretar ques- tões políticas que afetam diariamente suas vidas, e, ainda, aperfei- çoar os modos de formular verbalmente questões tidas como rele- vantes (MARQUES, 2007, p. 155)

A diferença crucial entre entrevistas individuais e grupos focais é que os últimos permitem a coleta de dados no contexto de interação mais amplo, em que há o estímulo para que os entrevistados respondam uns aos outros. (Kitzinger; Barbour, 2001) Essa característica também os distingue de outras formas de entrevistas em grupo. De acordo com Kitzinger e Barbour (2001), nos grupos focais, as interações são consideradas para geração de dados de análise, e não apenas as falas isoladas dos participantes:

\begin{abstract}
Ao invés de perguntar questões a uma pessoa de cada vez, os pesquisadores de grupo focal encorajam os participantes a conversar entre eles: fazendo perguntas, trocando anedotas e comentando acerca das experiências e dos pontos de vista dos outros. No mínimo, os participantes da pesquisa criam um público para o outro (KITZINGER; BARBOUR, 2001, p. 4, tradução nossa)
\end{abstract}

Desse modo, compreendemos os grupos focais como contextos de interaçãonos quais há produção discursiva, e não como espaço de checagem de resultados de sondagens de opinião, como eles são normalmente vistos pela pesquisa mer-

8 Lamarão (2008) realizou uma pesquisa sobre estigma e subalternidade no trabalho infantil a partir de entrevistas individuais com oito senhoras que haviam sido trabalhadoras domésticas na infância. 
cadológica. (KITZINGER; BARBOUR, 2001; MORGAN, 1997) Afinal, os "grupos focais são eles mesmos um contexto social” (WILKINSON, 2001, p. 66, tradução nossa) que propicia ao investigador observar como os sentidos são construídos de modo conjunto por meio da interação entre os participantes.

Barbour chama atenção para o caráter situado e contextual das interações nos grupos focais. De modo complementar, Callaghan, citada por Barbour (2009), afirma que, dependendo do modo como os grupos focais são organizados, eles podem acessar conhecimentos e perspectivas que compõem o habitus de determinados grupos, fazendo clara referência à teoria de Bourdieu sobre o assunto.

Como observa Morgan, "grupos focais são úteis quando se trata de investigar o que os participantes pensam, mas eles são excelentes em desvendar porque os participantes pensam como pensam”. (MORGAN apud BARBOUR, 2009, p. 56) Assim, por conta dos possíveis ganhos analíticos, decidimos investir nessa forma de pesquisa de campo bastante exigente do ponto de vista da logística, da criação de condições de realização, dos desafios da moderação, da dificuldade de registrar aqueles momentos mais complexos do que o gravador poderia alcançar e das formas de se analisar esse material.

Apesar de reconhecermos as potencialidades do método de grupos focais, procuramos manter uma postura constantemente crítica em relação ao papel deles na pesquisa e às formas pelas quais os estávamos conduzindo. Desse modo, como apresentaremos mais adiante, tivemos o cuidado de realizar grupos exploratórios para verificar a validade do método em fornecer respostas ao nosso problema de pesquisa. Roteiros, questões, perfis das entrevistadas foram pensados à luz da experiência de realização de grupos iniciais.

Duas questões merecem ser destacadas em relação aos grupos focais com sujeitos considerados "vulneráveis" ou "oprimidos": (a) como lidar com temas sensíveis?; (b) como acessar o que seria a "verdade” nas falas dos entrevistados? Com o propósito de esclarecer nossa posição acerca dessas indagações, iremos discuti-las a seguir.

COMO LIDAR COM TEMAS SENSÍVEIS?

Um dos desafios enfrentados desde o início era como realizar os grupos focais acerca das relações de poder no TID de modo a não causar constrangimentos para meninas e mulheres que foram trabalhadoras na infância e na adolescência. 
Para Klocker (2012), ao trazer à tona casos de exploração e de violência, há o risco de afetar negativamente as entrevistadas por meio da recordação de situações tristes que poderiam estar esquecidas. Nesse sentido, a autora argumenta que o TID é um tema sensível que demanda especial atenção do investigador na realização e na condução de entrevistas".

Segundo Barbour (2009), a “delicadeza” de um assunto não é algo inerente a ele, mas o produto de um processo cultural e social. A pesquisadora argumenta que grupos focais podem ser utilizados para coleta de dados em grupos de distintos indivíduos tidos como "vulneráveis" acerca de temas "difíceis”, como, por exemplo, pesquisas empreendidas com garotas suecas acerca de sexualidade e aborto, com pacientes terminais acerca dos cuidados no fim da vida, ou ainda com doentes mentais. Na nossa pesquisa, a dificuldade é não afetá-las negativamente com as discussões nos grupos focais e, ao mesmo tempo, buscar um meio termo para que a abordagem não fique superficial ou amena demais a ponto de desfavorecer a pesquisa.

Tal perspectiva está de acordo com a de Farquhar (2001), que defende a necessidade de o pesquisador refletir acerca do que é julgado como tema sensível e por quem. Nessa perspectiva, é essencial que se avalie o quanto que um desenho de pesquisa pode ser sensível "em razão do com quem queremos conversar, quem nós somos ou sobre o que queremos conversar. Somente então é possível avaliar com propriedade a adoção de um método particular como os grupos focais”. (FARQUHAR, 2001, p. 49, tradução nossa) Após essa etapa, de acordo com a autora, é essencial também refletir sobre as implicações que a realização de grupos focais pode trazer para o estudo em curso e para os sujeitos envolvidos na pesquisa, tanto entrevistados quanto pesquisadores. (FARQUHAR, 2001)

Sobre a realização de grupos focais acerca de temas sensíveis, Farquhar (2001) afirma que a configuração grupal favorece o compartilhamento de experiências e processos de autorrevelação mais do que entrevistas isoladas. Em razão disso e do perfil homogêneo das participantes, que estão ou estiveram en-

9 A pesquisa de Klocker (2012) foi realizada a partir de entrevistas individuais com adolescentes que estavam trabalhando em casas de família e adolescentes que já tinham sido trabalhadoras domésticas na Tanzânia. A questão principal perseguida pela autora eram as implicações metodológicas da comparação entre as perspectivas de atuais e antigas adolescentes trabalhadoras domésticas. A conclusão da autora é que ambas as perspectivas, quando combinadas, enriquecem e complexificam o entendimento acerca do trabalho infantil. (KLOCKER, 2012) 
volvidas com o TID, os grupos focais podem estimular a emergência de situações que não haviam sido expostas e discutidas (como, por exemplo, casos de abuso sexual de patrões). No entanto, como lidar com as consequências da exposição dessas situações durante o grupo e na vida de meninas e mulheres?

Farquhar apresenta algumas orientações em relação sobre como iniciar grupos focais sobre temas sensíveis. Atividades de aquecimento, explicações claras sobre o que está acontecendo e o que irá ocorrer em seguida, definição de regras, discussão sobre a possibilidade de gravação. Entretanto, é preciso ter bom senso em relação à escolha das atividades de aquecimento, sobretudo, quando o grupo a ser entrevistado é composto por adultos, porque eles podem não querer se engajar nesse tipo de atividade. Começar de um assunto menos pessoal para um mais pessoal também pode ajudar a desenvolver e estimular a discussão no grupo. (FARQUHAR, 2001) Morgan (1997) sugere, ainda, a adoção da estratégia do funil,na qual a discussão começa por assuntos sobre os quais os participantes possam facilmente falar e discutir para, paulatinamente, ir aprofundando em direção às temáticas principais.

Apesar dos desafios para lidar com temas sensíveis ou sujeitos vulneráveis em grupos focais, Farquhar (2001) ressalta que esse método de coleta de dados pode contribuir para dar voz a expressões e indivíduos por vezes pouco considerados na arena pública. "Podem criar um espaço relativamente seguro para a divulgação das experiências ou comportamentos que em outros contextos seriam vistos como tabu" (FARQUHAR, 2001, p. 62, tradução nossa) ou, no nosso caso, expressões de sujeitos inferiorizados, segundo hierarquias de valor sociais amplamente compartilhadas em nossa sociedade. (SOUZA, 2009)

Compreendemos, portanto, que o TID pode ser considerado um tema sensível em razão do perfil das pessoas entrevistadas (meninas e mulheres que foram ou são trabalhadoras infantis domésticas), uma vez que os conteúdos da discussão poderiam evocar a recordação e o testemunho de situações de violência. Ao mesmo tempo, acreditamos que o contexto interativo do grupo focal, quando construído entre sujeitos que compartilharam experiências semelhantes, pode atuar como espaço de tematização de elementos antes não discutidos. Assim, os grupos focais podem se configurar como espaços em que essas meninas e mulheres afetadas pelo TID podem fazer uso da palavra. Oferecer condições para que discutam sobre o assunto significa prestar atenção ao que elas têm a dizer (e como dizem) sobre as próprias vidas e sobre assuntos que lhes dizem respeito. 
COMO ACESSAR O QUE SERIA A “VERDADE" NAS FALAS

DOS ENTREVISTADOS?

Uma crítica comum a pesquisas que envolvem a investigação de sujeitos considerados subjugados por relações de poder refere-se à “incapacidade” dos entrevistados de fornecerem informações verdadeiras acerca de sua própria condição, na medida em que tudo que disserem será visto como resultado de processos ideológicos. Conforme apresentamos no início deste capítulo, na pesquisa sobre a ralé brasileira, Souza (2009) e colaboradores empreenderam um grande esforço e realizaram repetidas entrevistas com os mesmos sujeitos durante dois anos, visando a "reconstruir" a verdade acerca dos depoimentos de suas fontes, de tal forma que interesses e conflitos latentes pudessem ser apreendidos e interpretados.

A posição do autor é a de que, num primeiro momento de entrevista, as pessoas tendem a revelar e comentar sobretudo aspectos positivos da sua própria história, "maquiando", de certa forma, a realidade vivida. Com o desenrolar de outros momentos de questionamento, tenderiam a surgir mais paradoxos e ambiguidades do primeiro cenário construído pelo entrevistado.

A partir da literatura acerca de grupos focais e da experiência como moderadora, consideramos plausível afirmar que a dinâmica interativa desse método de coleta de dados possibilita a emergência dessas tensões e ambiguidades em relação aos depoimentos e relatos apresentados pelos sujeitos nos grupos. Isso porque, durante os processos de discussão nos grupos focais, pretensões de validade são testadas, questionadas e postas à prova constantemente pelos próprios participantes. Ainda assim, consideramos, tal como Klocker (2012), que não há uma única "verdade" a ser descoberta nas falas desses sujeitos. Não se trata de ouvir as falas dos entrevistados para descobrir a sua confiabilidade ou precisão, “o que é, então, de interesse não é se uma história é verdadeira, mas porque alguém opta por contá-la de modo particular”. (BARBOUR, 2009, p. 59)

Acerca desse assunto, consideramos, ainda, a posição de Portelli sobre a "verdade" das fontes de pesquisas em História Oral. Segundo ele, "o realmente importante não é ser a memória apenas um depositário passivo de fatos, mas também um processo ativo de criação de significações”. (PORTELLI, 1997, p. 33) Assim, a "utilidade" dessas fontes não está no fato de poderem relatar eventos e fatos passados, mas em como buscam atribuir sentido ao modo como a memória 
acomodou aquelas lembranças. (PORTELLI, 1997) Portanto, não é apenas a veracidade dos relatos que nos interessam, e sim o modo pelo qual eles dizem acerca das relações de poder em torno do TID.

Nas próximas seções, detalharemos como os grupos focais foram organizados, registrados, e as características das pessoas entrevistadas em cada um.

\section{REALIZAÇÃO DA PESQUISA EXPLORATÓRIA}

A partir dessas considerações acerca dos grupos focais, construímos as estratégias para coleta das falas de atuais e de ex-trabalhadoras infantis domésticas. Em princípio, tínhamos em mente entrevistar adolescentes que foram atendidas pelo Petid e adolescentes que não eram ligadas a projetos de enfrentamento dessa prática. Para avaliar as vantagens analíticas dessa diferenciação, e também a estrutura e o roteiro que havíamos elaborado, realizamos uma pesquisa de campo preliminar com a realização de dois grupos focais.

Com a finalidade de entrevistar adolescentes trabalhadoras domésticas desvinculadas de ações de enfrentamento a esse tipo de trabalho infantil, decidimos buscá-las no ambiente escolar, tal como havia sido feito no início do Petid por Lamarão, Menezes e Ferreira (2000). Como uma das promessas do TID é o acesso à educação, era plausível supor que encontraríamos meninas trabalhadoras domésticas em escolas públicas localizadas em bairros de classe média. Escolhemos um bairro de situação econômica mediana porque, em nossa pesquisa de mestrado (CAL, 2007), já havíamos identificado uma tendência atual de patroas de classes mais abastadas não contratarem meninas para o serviço doméstico em razão do trabalho que davam e dos problemas que causavam por não serem mais adolescentes tão "moldáveis", como elas consideravam as meninas que antigamente vinham do interior do Pará para trabalhar em casas de família.

O bairro escolhido foi o do Coqueiro, no município de Ananindeua, pertencente à Região Metropolitana de Belém. A escola selecionada possui cerca de 930 alunos, do $1^{0}$ ao $9^{\circ}$ ano..$^{10}$ Inicialmente, fizemos contatos com a diretora da escola para explicar a pesquisa e averiguar a possibilidade de realizar o grupo focal naquele ambiente. Explicamos à diretora alguns fatores que têm sido apon-

10 Os dados referem-se ao total de matrículas em 2011, obtido por meio de Censo Escolar, sistematizados pelo Portal Qedu (www.qedu.org.br), voltado para a qualidade da educação no país. 
tados por pesquisas (LAMARÃO; MACIEL, 2006) como característicos de adolescentes que trabalham: defasagem idade-série, rendimento insuficiente em razão do cansaço e das longas jornadas de trabalho. A partir disso, a própria diretora indicou adolescentes que poderiam estar na situação de TID.

Assim, o grupo focal foi realizado em 27 de abril de 2011 com cinco adolescentes de 15 anos que cursavam a sexta série do ensino fundamental. Todas eram naturais de municípios do interior do Pará: Curralinho e Santa Cruz do Arari, do Arquipélago do Marajó; Cametá, região do Baixo Tocantis e Bragança, localizado no nordeste do estado. Elas haviam vindo para Belém morar com outras famílias e estudar. Havia uma menina que veio morar com a irmã e que, durante meio período, trabalhava como babá. Tratavam-se, portanto, de situações típicas de TID, conforme discutimos no primeiro capítulo. Por meio desse grupo, foi possível constatar a necessidade de adequação do roteiro, principalmente da dinâmica inicial de aquecimento, que trazia dificuldade de entendimento às participantes, e de mudança na escolha do público a ser entrevistado na pesquisa. Durante esse grupo, pude identificar uma menina que vivia em condições precárias. Sob seus cuidados, ficavam dois idosos e uma criança. A adolescente trabalhava sete dias por semana, sem remuneração, não mantinha mais contato com a família, desde que começou a circular por diferentes casas, servindo como criada, em congruência com as situações apresentados por Motta-Maués (2008).

Percebemos a dureza e a dificuldade de não ter retaguarda nesta pesquisa para lidar com casos que necessitam de intervenção. Para Klocker (2012), trata-se de um conflito ético em que as pesquisas cujos sujeitos são crianças ou adolescentes marginalizadas devem visar, de algum modo, ao aprimoramento das condições de vida desses meninos e meninas. No entanto, naquela situação, percebemos que, ao mesmo tempo em que discutir sobre o TID poderia trazer ganhos em termos de crítica e reflexão, poderia também significar o reforço de uma situação de grave injustiça. ${ }^{11}$ Após esse grupo, decidimos realizar entre-

11 Como encaminhamento imediato e com o consentimento da adolescente, decidimos conversar com a diretora da escola acerca do problema para que houvesse um entendimento mais amplo da situação da menina, de tal forma que os professores não a vissem como alguém que não queria estudar, e sim procurassem saídas para que ela tivesse oportunidade de aprender nas aulas. Também encaminhamos o caso ao Centro de Referência Especializado de Assistência Social (CREAS) do município e nos colocamos à disposição da escola para pensar ações e palestras acerca do trabalho infantil. 
vistas com meninas que estivessem amparadas por algum tipo de retaguarda, como, por exemplo, instituições religiosas e organizações sociais.

Para realização do outro grupo focal dessa fase exploratória, convocamos adolescentes que haviam sido atendidas pelo Petid. Por meio de contatos telefônicos, decidimos o lugar mais apropriado em termos de localização e agendamos o grupo para 30 de abril de 2011, numa sala de aula do Campus BR da Unama. Apesar de termos convocado seis adolescentes, apenas três efetivamente compareceram. Delas, duas tinham 14 e uma, 15 anos. Quanto aos anos de atendimento do Petid, uma passou mais de quatro anos ligada ao Programa, e duas, menos de um ano. Esse grupo foi essencial para chamar atenção para as tensões do TID na própria casa onde as meninas vivem com suas famílias e o modo como isso foi discutido pelo grupo. As adaptações que realizamos no roteiro em relação à dinâmica de aquecimento, sobretudo, mostraram-se adequadas.

Esses momentos também foram fundamentais para nosso aprimoramento na função de moderadora. Apesar de já termos bastante experiência na condução de grupos focais com mulheres adultas (CAL, 2007), trabalhar com adolescentes nos impunha novos desafios em relação à linguagem e à postura no grupo. Também observamos que o fato de a moderadora aparentar ser um pouco mais velha que as entrevistadas não representou problemas para a discussão nos grupos, nem houve distinções de cor da pele, pois a aparência física da moderadora era é a do tipo médio das mulheres paraenses. Essas características referentes à idade, cor da pele e pertencimento à comunidade do moderador em relação aos entrevistados têm sido apontadas por diversos autores como essenciais para a condução adequada desse tipo de pesquisa de campo. (BARBOUR, 2009; KLOCKER, 2012)

\section{PESQUISA DE CAMPO E REALIZAÇÃO DOS GRUPOS FOCAIS}

No período de 4 a 26 de junho de 2011, realizamos sete grupos focais com intuito de coletar efetivamente material para análise. ${ }^{12}$ A partir das informações que havíamos obtido na pesquisa exploratória e de sugestões recebidas durante

12 Cada grupo durou cerca de duas horas, e as participantes receberam, a título de ajuda para deslocamento, a importância de $\mathrm{R} \$ 10,00$ (dez reais). 
discussões acerca da tese no âmbito do Grupo EME/UFMG, diversificamos as características das meninas e mulheres entrevistadas para composição dos grupos.

Dessa forma, organizamos os grupos em torno dos seguintes perfis: meninas trabalhadoras domésticas não ligadas a programas sociais de combate ao TID; meninas ex-trabalhadoras domésticas ligadas ao projeto social do CedecaEmaús; senhoras ex-trabalhadoras infantis domésticas atendidas por projeto social; mulheres jovens ex-trabalhadoras infantis domésticas não ligadas a projetos sociais; mulheres ex-trabalhadoras infantis domésticas empregadas em condomínio de classe média/alta e, por fim, mulheres ex-trabalhadoras infantis domésticas sindicalizadas. ${ }^{13}$

Nossa preocupação, portanto, não era a representatividade estatística da amostra, mas sim a busca por diversidade de características e perfis dos sujeitos entrevistados que nos possibilitasse realizar de modo mais abrangente a análise das relações de poder e da configuração política do TID. Por esse motivo, selecionamos tanto meninas e mulheres engajadas, ou pelo menos envolvidas, com projetos sociais quanto pessoas que não participam de Programas ou movimentos sociais. Nesse sentido, adotamos a perspectiva de Barbour (2009):

\begin{abstract}
A questão aqui não é o número de tais indivíduos na população como um todo, mas sim os insights que podem ser obtidos por meio dessas exceções e o seu potencial para colocar sob um foco ampliado alguns dos pressupostos tidos como evidentes ou processos que de outra forma não são notados. (BARBOUR, 2009, p. 86)
\end{abstract}

Assim, a diversidade de perfis das meninas e mulheres entrevistadas tende a nos proporcionar uma teia maior de discursos e posicionamentos acerca do TID. Inclusive a distância temporal entre quem era trabalhadora infantil doméstica e quem havia sido no momento da pesquisa de campo deve ser considerada.

13 Além da nossa pesquisa de campo, realizamos, ainda, mais três grupos focais, cujo foco principal era coletar material para a pesquisa "Reconhecimento, Deliberação e os media: entre a experiência e os discursos de justificação", do Grupo de EME/UFMG. Assim, o grupo das empregadas domésticas ligadas ao sindicato foi entrevistado em dois momentos. Como no primeiro o tempo para discussão foi reduzido em função de uma necessidade de uso do local pelo Sindicato, optamos por considerar os resultados de ambos os grupos na análise desta tese, os quais serão indicados por "Sindicato I" e "Sindicato II". Importante ressaltar que seis participantes estiveram no primeiro encontro e, dessas, apenas uma faltou ao segundo. Cada participante só foi considerada uma única vez na construção dos perfis das meninas e mulheres entrevistadas. 
Segundo Klocker, o tempo não é um medium neutro nessas circunstâncias. De acordo com o estudo desenvolvido por essa autora, os sujeitos que não estavam trabalhando tinham maior probabilidade de questionar situações consideradas injustas. (KOCLER, 2012)

Para que as discussões em grupo pudessem ser produtivas, limitamos o número de participantes por grupo em no máximo oito. Apesar dos convites terem sido feitos para essa quantidade de pessoas, já era esperado que algumas faltassem. A composição final dos grupos variou entre três e sete participantes. Consideramos essa quantidade adequada. Segundo Barbour (2009), “é perfeitamente possível fazer um grupo com três ou quatro participantes" (BARBOUR, 2009, p. 89), principalmente no caso de temas considerados sensíveis.

Com objetivo de convocar as participantes, optamos por diferentes estratégias, porque o trabalho infantil investigado ocorre no interior de lares de família, o que dificulta o contato com essas pessoas. Em relação às mulheres adultas, era preciso identificar as que haviam sido trabalhadoras na infância. Normalmente, contamos com a ajuda de informantes e pessoas de referência que foram nossos contatos para escolha das participantes e organização dos grupos. Os principais foram: funcionários e antigos funcionários do Cedeca-Emaús, que nos ajudaram na realização de três grupos; a presidente do Sindicato dos Trabalhadores Domésticos de Belém e Ananindeua; uma mulher trabalhadora doméstica que identificamos durante nossa pesquisa de mestrado e que contribui para organizarmos o grupo com jovens adultas não ligadas a movimentos sociais e, por fim, porteiros de um condomínio de classes média e alta que nos ajudaram a identificar mulheres que haviam sido trabalhadoras domésticas na infância e conseguiram os contatos delas para que nós fizéssemos o convite.

Os locais de realização dos grupos foram diversificados, mas a principal condição para escolha era a proximidade com o local de moradia ou trabalho das participantes, e ainda a familiaridade delas com o lugar. Assim, foram utilizados desde espaços em centros de formação religiosos até a casa de uma das patroas. De acordo com Barbour (2009), "a localização exerce certa influência na discussão, e é importante considerar as conotações que uma localização em particular possa ter aos participantes”. (BARBOUR, 2009, p. 75-76) Sobre esse assunto, merece destaque o grupo realizado na casa da patroa. A primeira ideia era de que ele fosse conduzido no pátio da casa, uma continuação da sala. O local estava reservado para isso, e a patroa tinha se ausentado. Contudo, percebemos que as 
entrevistadas estavam desconfortáveis. Questionamos, então, onde elas gostariam de ser entrevistadas, e uma delas não titubeou: “vamos para cozinha!”. As outras, prontamente, concordaram e, a partir daí, as interações e discussões no grupo ocorreram normalmente.

O fato de termos utilizado diferentes ambientes para a realização dos grupos focais não nos parece um fator complicador. Ao contrário, como afirma Barbour (2009), ter consciência das conotações associadas a espaços distintos "pode significar uma contribuição significativa para análise”. (BARBOUR, 2009, p. 76)

A respeito do registro desses grupos, optamos pela gravação do áudio ${ }^{14}$ e pelo registro de observações acerca do andamento dos grupos e do contexto em que foram realizados. Apesar de alguns autores afirmarem que inserir um mecanismo de gravação modifica o processo interativo (ELIASOPH, 1998; WALSH, 2004), avaliamos que era o modo mais seguro para registrar esses momentos e solicitamos a concordância verbalizada das entrevistadas logo no início das seções.

De modo complementar, os grupos, em geral, foram acompanhados por uma observadora que registrava as sequências das falas para termos como material auxiliar no momento de identificação das entrevistadas nas transcrições. ${ }^{15}$ Pedíamos, ainda, que cada entrevistada preenchesse uma ficha de identificação, onde solicitávamos informações sobre naturalidade, estado civil, escolaridade, família, consumo de media, experiência de trabalho, renda familiar e participação em grupos ou projetos sociais.

Os grupos focais foram realizados a partir de um roteiro semiestruturado (Apêndice B) que consistia em quatro momentos principais: (a) apresentação e dinâmica de aquecimento, a partir da construção de um crachá; (b) discussão sobre lugares de origem, relações familiares e divisão das tarefas da casa, que era, aos poucos, afunilada para a temática do TID; (c) apresentação de trechos de matérias dos media e discussão; (d) informações finais e avaliação do encontro.

14 Temos uma dívida especial com o Grupo EME, especialmente com a Profa. Rousiley Maia e a bolsista Thaiane Rezende, que cuidaram para que o EME adquirisse um gravador digital semiprofissional, o que foi decisivo para o registro e transcrição dos grupos. Embora potente, o gravador é pequeno, possui cerca de $20 \mathrm{~cm}$, o que contribuiu para não causar constrangimentos nos grupos.

15 Contamos com duas então acadêmicas da Unama nessa função: Camila Aquino (três) e Carolina Solyno (um). Num dos grupos, contamos, ainda, com o apoio de Larissa, bolsista do Cedeca-Emáus. Em dois, não foi possível contar com assistentes. 
Oferecemos às participantes um lanche antes do início dos grupos focais, como demonstração de cordialidade e de estimulo à aproximação entre elas e a moderadora. Em seguida, explicávamos em linhas gerais a proposta da pesquisa e da realização daquele encontro, apresentávamos algumas informações sobre o funcionamento do grupo, como, por exemplo, que as identidades delas seriam preservadas e cada uma escolheu um apelido pelo qual gostaria de ser chamada nesta pesquisa. Introduzíamos o porquê da necessidade de gravar aquela conversa e solicitávamos concordância verbalizada das entrevistadas.

Para apresentação às participantes, selecionamos cinco trechos de matérias jornalísticas publicadas em O Liberal e Diário do Pará no período investigado. O critério principal de escolha foi que representassem significativamente o modo pelo qual meninas e mulheres ex-trabalhadoras domésticas eram mostradas pelos jornais. Os trechos, então, eram reproduzidos em cartazes A3, para fácil visualização, e também eram entregues por escrito às participantes. Realizávamos a leitura do texto em voz alta e, normalmente, líamos duas vezes antes de começar a discussão de cada um.

Durante os grupos focais, procurávamos não tecer juízos de valor e não apresentar nossas opiniões acerca dos assuntos tratados. Apenas fazíamos indagações e orientávamos a discussão. Em alguns momentos, relatamos casos pessoais, como dilemas do início do casamento sobre a divisão das tarefas domésticas e algumas outras situações que estimularam a interação e a identificação entre moderadora e entrevistadas. Poucas vezes, ao final dos grupos, foi preciso retomar alguns pontos e inclusive fazer esclarecimentos, principalmente sobre a legislação. Como afirmam Kitzinger e Barbour (2001), após o encerramento do grupo focal, é um dever ético do pesquisador corrigir informações imprecisas ou equivocadas que tenham surgido durante a discussão.

\section{PERFIS DAS PARTICIPANTES DOS GRUPOS FOCAIS}

No total, entrevistamos 27 meninas e mulheres cujas idades variaram de 12 a 68 anos, sendo que a maioria $(48,1 \%)$ estava acima dos 40 . O percentual restante era composto por adolescentes de 12 a 16 anos (37\%) e mulheres entre 20 e 39 anos $(14,8 \%)$. Quanto à localidade de origem, portanto, antes da inserção no serviço doméstico, 48,1\% delas vieram do interior do Pará, o que corrobora os estudos 
apresentados no primeiro capítulo sobre a vinda de meninas de outros municípios para exercerem trabalho doméstico na capital, 44,4\% eram de Belém e 7,4\% vieram de municípios do Maranhão.

Em relação às funções exercidas quando começaram a trabalhar, 40,7\% das entrevistadas afirmou que desenvolvia funções domésticas em geral, 33,3\% eram babás e 14,8\% disseram não trabalhar fora, "só em casa". ${ }^{16}$ Esse dado é relevante para entendermos o quanto os serviços realizados dentro de casa por meninas não são vistos como um trabalho, ainda que demandem longas jornadas e que essas meninas sejam as únicas responsáveis por cuidar da casa e cozinhar para a família.

Merece destaque ainda, o fato de que a grande maioria das entrevistadas começou a trabalhar entre os 4 e os 13 anos de idade $(66,7 \%)^{17}$ e que não recebiam remuneração pelas atividades exercidas (70,4\%). Das que recebiam pagamento, apenas duas afirmaram receber um salário mínimo. As outras relataram receber entre cerca de $R \$ 30$ e $R$ \$ 200 reais por mês. As que não recebiam dinheiro informaram que ganhavam roupas, calçados, alimentação e, algumas, material escolar.

Quanto ao grau de escolaridade, 33,3\% estavam cursando o ensino fundamental na época da entrevista e outros $29,6 \%$ disseram ter parado de estudar antes de completar o ensino fundamental. Três mulheres $(11,1 \%)$ responderam que tinham concluído esse nível de ensino, duas $(7,4 \%)$ que não haviam terminado o ensino médio, quatro $(14,8 \%)$ declararam tê-lo finalizado e uma $(3,7 \%)$ ainda o estava cursando.

Questionamos ainda as participantes acerca da ocupação que exerciam na época da realização dos grupos. Continuavam trabalhando com serviços domésticos, $48,1 \%$ delas; porém, $18,5 \%$ dessas, encontravam-se desempregadas. O principal motivo apontado por elas próprias era o fato de terem mais de 40 anos, o que dificultava a contratação para esse tipo de serviço. Declaram-se estudantes, $18,5 \%$, donas de casa, $11,1 \%$, estudantes que trabalham, $11,1 \%$ (sendo duas em serviços domésticos e uma em vendas), entregadora de pastel, consultora de venda e autônoma tiveram a mesma ocorrência: cada um 3,7\%.

16 Os outros $11,1 \%$ correspondem a três entrevistadas: uma que disse ser entregadora de pastel, outra doméstica e babá e a terceira afirmou que vendia DVDs nos semáforos.

17 De 4 a 9 anos: 33,3\%; de 10 a 13 anos, 33,3\%; entre 14 e 15 anos, 7,4\%; 16 anos, 3,7\% e não informaram, $22 \%$. 
Sobre as condições de moradia e renda, a média de pessoas moradoras nas casas das entrevistadas era de cinco, e o máximo chegou a 11 indivíduos vivendo sob o mesmo teto. Chama atenção o fato de que, apesar de uma composição familiar grande, a tendência é que poucos membros recebam salário, de tal forma que maior parte das entrevistadas (74\%) declarou ter renda familiar de até dois salários mínimos.

De modo geral, os perfis das participantes dos grupos focais que realizamos coadunam as informações obtidas por pesquisas anteriores (INTERNATIONAL LABOUR ORGANIZATION, 2013; LAMARÃO, 2008; LAMARÃO, MENEZES, FERREIRA, 2000; LAMARÃO, 2008), o que, a nosso ver, reforça certa representatividade "típica", ainda que não estatística, das nossas fontes.

Uma informação coletada diferenciada em relação a esses outros estudos é sobre o costume de ler jornais. Apesar de não pretendermos estabelecer nenhuma causalidade direta entre o consumo de informação midiática e a forma pela qual as matérias foram interpretadas, pareceu-nos relevante consultar as entrevistadas sobre a frequência com a qual liam jornais e quais jornais costumavam ler. Das 27 entrevistadas, 18 disseram consumir informações dos media, sendo que a maioria $(55,6 \%)$ o faz todos os dias, sobretudo nas casas dos patrões. A preferência por jornal está dividida: das 25 indicações de periódicos feitas por elas, 44\% foram do Diário do Pará e 40\% de O Liberal. O Amazônia Jornal, que é uma versão popular do grupo O Liberal, recebeu 16\% das indicações.

\section{CARACTERÍSTICAS DOS GRUPOS FOCAIS}

Optamos por nomear os grupos focais preferencialmente de acordo com os lugares onde foram realizados:

1) Grupo do Centro de Formação - contou com a participação de cinco adolescentes de 14 e 15 anos e foi conduzido num de Centro de Formação, vinculado à Igreja Católica, no bairro da Terra Firme, em Belém, no dia 4 de junho de 2011, um sábado pela manhã, quando o grupo de jovens da Igreja normalmente se encontra. Apesar de terem relação com as atividades de formação religiosa, consideramos que eram adolescentes não vinculadas a projetos sociais de enfrentamento ao trabalho infantil; 
2) Grupo do Projeto Social - foi composto por cinco adolescentes de 12 a 16 anos que participavam de um projeto social do Cedeca-Emaús, cuja finalidade era prestar atendimento a meninas vítimas de violência, principalmente sexual. Elas passavam por oficinas e momentos de formação e se reuniam constantemente com a educadora que as acompanhava. Organizamos o grupo focal numa quarta-feira, quando esses encontros normalmente ocorriam, dia 8 de junho de 2011. Consideramos as participantes sujeitos envolvidos com projetos sociais de enfrentamento ao TID por ser essa uma temática prioritária para o Cedeca-Emaús;

3) Grupo do Sindicato I - participaram seis mulheres entre 42 e 57 anos, sendo quatro sindicalizadas há um ano, uma, há seis anos e outra, há 13 anos. O grupo ocorreu no dia 10 de junho de 2011, na sala da sede do Sindicato dos Trabalhadores Domésticos, Arrumadores e Camareiros (Sintdac) dos municípios de Belém e Ananindeua, localizado no bairro Comércio, em Belém;

4) Grupo do Sindicato II - participaram cinco mulheres entre 42 e 57 anos, sendo quatro sindicalizadas há um ano e uma, há seis anos. Como essas mulheres ligadas ao Sindicato moravam em Ananindeua, elas preferiram que o grupo fosse realizado em lugar mais próximo de suas residências, assim, o local escolhido, pela disponibilidade e pela localidade, foi o Campus BR da Unama. O grupo foi realizado em 16 de junho de 2011;

5) Grupo Condomínio - foi composto por cinco mulheres que tinham entre 34 e 51 anos e trabalhavam formalmente como empregadas domésticas em um condomínio de classe média/alta em Ananindeua, na Região Metropolitana de Belém. O grupo foi realizado em 15 de junho de 2011 numa área comum do condomínio, após o horário de trabalho das participantes. A maior dificuldade que enfrentamos foi conciliar os diversos horários de saída das mulheres entrevistadas, o que só foi possível porque algumas conseguiram negociar a saída mais cedo com os patrões;

6) Grupo Cidade de Emaús - envolveu cinco mulheres de 51 a 57 anos. Todas oriundas de municípios do interior do Pará, mas que já residiam em Belém há bastante tempo. Foi o grupo com menor grau de escolaridade: apenas uma havia concluído o ensino fundamental. As outras não 
chegaram a completá-lo. O grupo foi realizado em 17 de junho de 2011, na Cidade de Emaús, sede da Organização Não Governamental (ONG) Movimento República de Emaús, organização ao qual o Cedeca é vinculado. Elas relataram participar de atividades recreativas e educativas desenvolvidas nesse espaço há pelo menos três anos e, portanto, aquele ambiente lhes era bastante familiar;

7) Grupo Casa da Patroa - contou com a participação de três jovens adultas, de 26, 27 e 28 anos. Duas trabalhavam como domésticas desde os 13 anos de idade e uma desde os oito. O grupo ocorreu em 26 de junho de 2011 na casa da atual patroa de uma delas, localizada no bairro Castanheira, em Belém. Como a pesquisa abordava principalmente as relações de trabalho durante a infância e adolescência, não tivemos problema para obter o consentimento da patroa para realização desse grupo focal. As outras duas entrevistadas estavam acostumadas a frequentar essa casa porque visitavam a colega no local de trabalho, tanto que já eram conhecidas pela família empregadora.

Neste capítulo, apresentamos a importância de considerarmos tanto as perspectivas dos media quanto as das afetadas para entendimento sobre como o jogo entre relações de poder atua na configuração política do trabalho infantil. Esclarecemos ainda, nossas escolhas metodológicas e apresentamos os materiais que compõem nosso corpus. No próximo capítulo, discutiremos as categorias analíticas que construímos para apreciação dos textos dos media e das falas de meninas e mulheres envolvidas com o TID e iniciaremos a análise propriamente. 